\title{
1,3- vs. 1,5-Cyclization of azomethine ylides derived from 1-azabuta-1,3-dienes and difluoro- and dichlorocarbenes. Experimental and quantum-chemical study
}

\author{
Alexander F. Khlebnikov, ${ }^{* a}$ Mikhail S. Novikov, ${ }^{a}$ Stanislav A. Dolgikh, ${ }^{\text {a }}$ and Joerg Magull ${ }^{\text {b }}$ \\ ${ }^{a}$ Department of Chemistry, St. Petersburg State University, Universitetskyi pr. 26, 199504 St. \\ Petersburg, Russia \\ ${ }^{b}$ Institut für Anorganische Chemie, Georg-August-Universität, Tammannstrasse 4, D-37077 \\ Göttingen, Germany \\ E-mail: Alexander.Khlebnikov@pobox.spbu.ru
}

Dedicated to Prof. Oleg Kulinkovich on the occasion of his 60th birthday

\begin{abstract}
1,3- vs. 1,5-Cyclization of azomethine ylides derived from 1-azabuta-1,3-dienes and difluoroand dichlorocarbenes, leading to halogenosubstituted aziridine or pyrrole derivatives, was investigated. Calculations of the reaction profiles were carried out at the B3LYP/6-31G* level to evaluate factors responsible for the predominant transformation pathways of the ylides.
\end{abstract}

Keywords: 1-Azabuta-1,3-dienes, difluorocarbene, dichlorocarbene, azomethine ylides, cyclizations, pyrroles, quantum-chemical calculations

\section{Introduction}

Azomethine ylides formed by carbene reactions with 1-azabuta-1,3-dienes can potentially undergo 1,3-cyclization to aziridines or 1,5-cyclization to form pyrrolines (Scheme 1). ${ }^{1}$

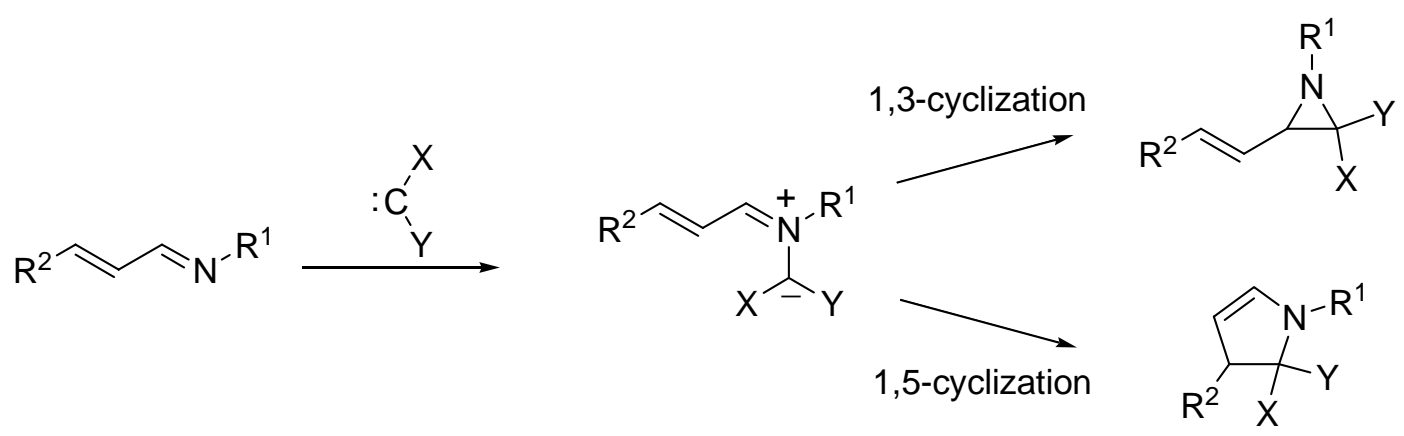

Scheme 1 
Reactions of carbenes and carbenoids with 1-azabuta-1,3-dienes have been studied poorly and only on an example of halosubstituted carbenes. ${ }^{1,2}$ The reaction of $N$-phenylimine of cinnamic aldehyde with dichlorocarbene resulted in the preparation of 2,2-dichloro-1-phenyl-3styrylaziridine (yield 64\%) formed by 1,3-cyclization of the corresponding azomethine ylide. ${ }^{3}$ By contrast, azomethine ylides generated from $N$-alkyl-1-azabuta-1,3-dienes and aryl(chloro)carbenes undergo 1,5-cyclization to give 1,2,3-trisubstituted pyrroles in 15-65\% yields. ${ }^{4}$ gem-Difluoroaziridines which might be expected to arise from 1,3-cyclization of difluoroazomethine ylides formed by the reaction of difluorocarbene with imines have never been detected in such reactions. ${ }^{2,5-7}$ At the same time, the products of the 1,5-cyclization of difluoroazomethine ylides, involving the $\mathrm{C}=\mathrm{C}$ bond of the furan ring, have been obtained in good yields in the reaction of difluorocarbene with $N$-(5-R-furan-2-ylmethylidene)anilines. ${ }^{6}$ Since the formation of difluoroazomethine ylides in the reaction of difluorocarbene with imines have also been evidenced by the 1,3-dipolar cycloaddition to activated acetylenes and ethylenes, ${ }^{2,5-7}$ difluoroaziridines can be obtained by intramolecular nucleophilic substitution and are fairly stable, ${ }^{8}$ the reason why these compounds do not form in the reaction of difluorocarbene with the $\mathrm{C}=\mathrm{N}$ bond is unclear. The aim of the present experimental and theoretical research was to find out factors responsible for the nature of products of the reactions of difluoro- and dichlorocarbenes with 1-azabuta-1,3-dienes and for the direction of cyclization of halosubstituted azomethine ylide intermediates.

\section{Results and Discussion}

We studied the reactions of difluoro- and dichlorocarbenes with 1-azabuta-1,3-dienes 1a-d (Scheme 2).

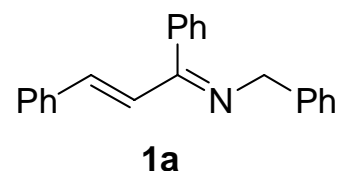

$1 a$

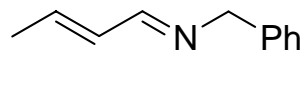

$1 \mathbf{b}$

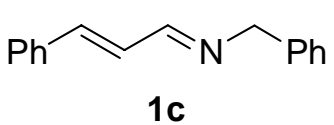

1c

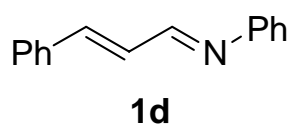

\section{Scheme 2}

Difluorocarbene was generated by reduction of dibromodifluoromethane with active lead (obtained by reduction of aqueous lead acetate with sodium borohydride) in dichloromethane in the presence of tetrabutylammonium bromide under ultrasound irradiation. Dichlorocarbene was generated by thermal decomposition of sodium trichloroacetate in chloroform in the presence of benzyltriethylammonium chloride (TEBA).

It was found that the result of the reaction of azadiene 1a with difluorocarbene depends on the quantity of the source of difluorocarbene introduced in reaction. With 1.2 eq of the source of difluorocarbene, we isolated as the major product fluoropyrrole 2 (yield 23\%). This product 
probably arises via intermediate formation of difluoroazomethine ylide 3, 1,5-cyclization of the latter into difluoropyrroline 4, and subsequent HF elimination (Scheme 3).

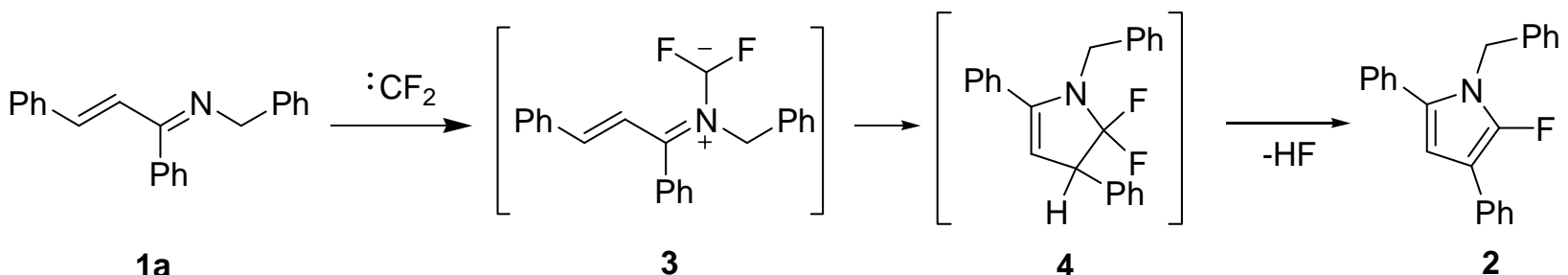

\section{Scheme 3}

The reaction with a double excess of the source of difluorocarbene gave, along with fluoropyrrole 2 (17\%), trifluoromethylpyrrole 5 (13\%) whose structure was proved by X-ray diffraction (Figure 1). With a triple excess of the source of difluorocarbene, trifluoromethylpyrrole 5 formed as a single product and was isolated in 34\% yield (Scheme 4).

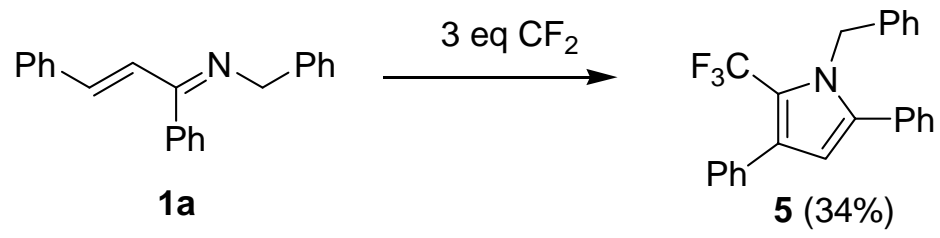

\section{Scheme 4}

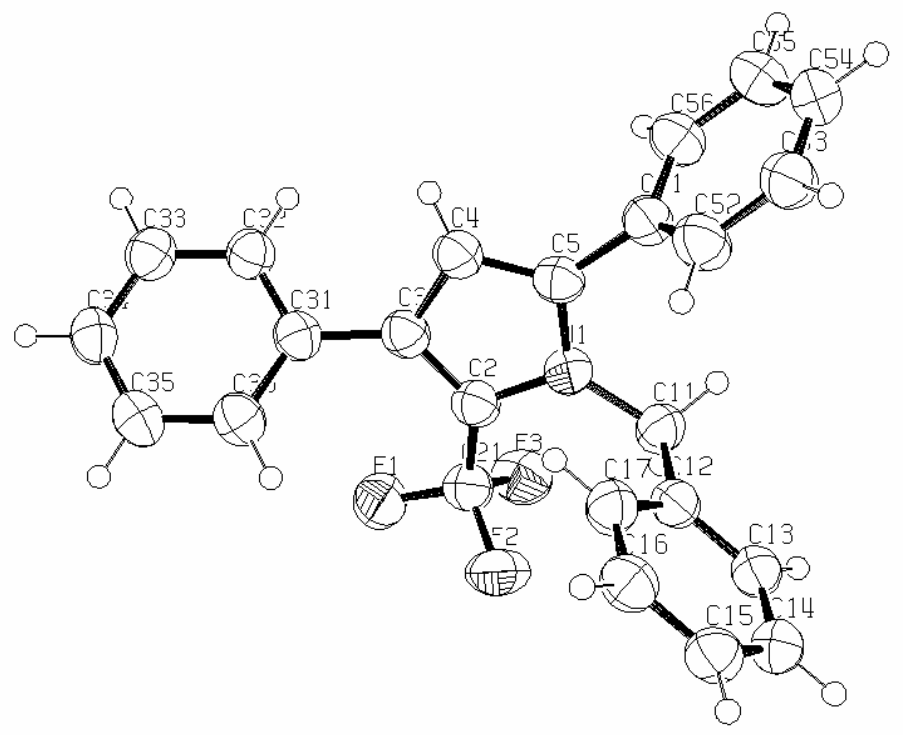

Figure 1. Perspective view of the X-ray crystal structure of 5. 
The formation of trifluoromethylpyrrole 5 can be explained either by difluorocarbene insertion into the $\mathrm{C}-\mathrm{F}$ bond of fluoropyrroline $\mathbf{4}$ or by cyclopropanation of pyrrole $\mathbf{2}$ to form cyclopropapyrrole $\mathbf{6}$ with subsequent heterolytic cleavage of the C-C-bond in the three membered ring under action of fluoride ion (Scheme 5).

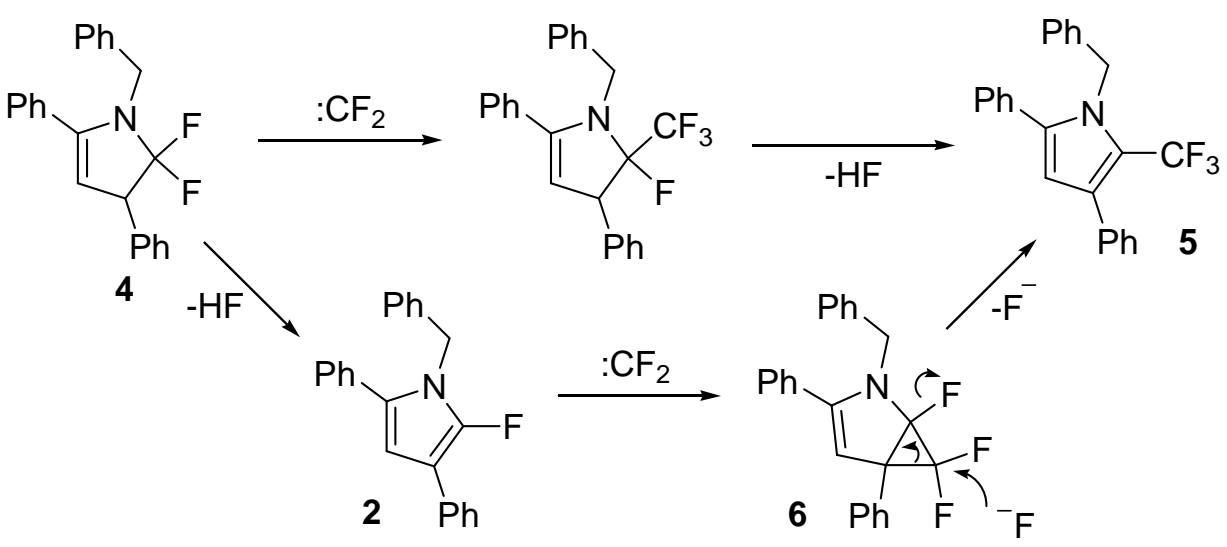

\section{Scheme 5}

The reactions of difluorocarbene with 1-azabuta-1,3-dienes 1b-d yielded no identifiable products.

The reaction of azadiene 1a with dichlorocarbene resulted in preparation of compound 7 in $35 \%$ yield (Scheme 6). The structure of the product 7 was proved by ${ }^{1} \mathrm{H},{ }^{13} \mathrm{C}$ NMR spectroscopy and elemental analysis.
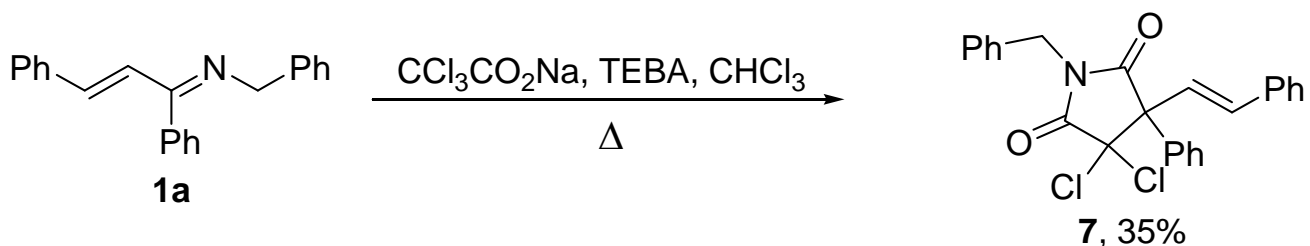

\section{Scheme 6}

The probable route to compound 7 involves formation of ylide 8, subsequent 1,3-cyclization of the latter into aziridine 9, and, finally, conversion of this unstable product into imidoyl chloride $\mathbf{1 0}\left(c f .{ }^{9}\right)$. 
<smiles>ClC(Cl)[N+](Cc1ccccc1)=C(C=Cc1ccccc1)c1ccccc1</smiles>

9

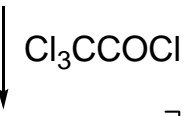

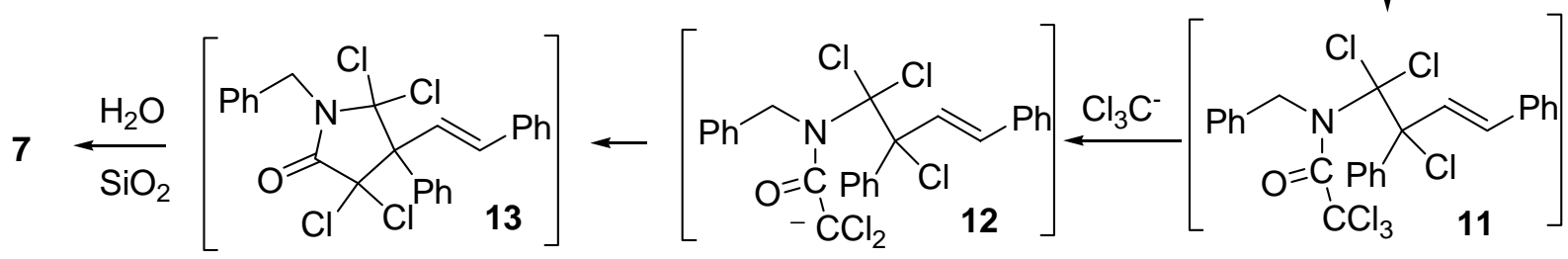

\section{Scheme 7}

The latter takes up trichloroacetyl chloride formed by thermolysis of the source of dichlorocarbene (sodium trichloroacetate) to give adduct 11. The adduct undergoes halophilic attack with trichloromethide to form anion $\mathbf{1 2}$ which cyclizes into pyrrolidone $\mathbf{1 3}$ whose subsequent hydrolysis gives rise to final reaction product 7 (Scheme 7). Similar processes were earlier observed in the hydrodechlorination of trichloroacetamides under the conditions of thermocatalytic decomposition of sodium trichloroacetate in chloroform. ${ }^{10}$

The reactions of azadienes $\mathbf{1 b}, \mathbf{c}$ with dichlorocarbene afforded both 1:1 adducts, chloropyrroles $14 \mathbf{a}, \mathbf{b}$, and pyridine derivatives $15 \mathbf{a}$ and $\mathbf{1 6} \mathbf{a}, \mathbf{b}$ formed from one molecule of azadiene and two molecules of dichlorocarbene (Scheme 8). The structures of all compounds were proved by ${ }^{1} \mathrm{H},{ }^{13} \mathrm{C}$ NMR spectroscopy and elemental analysis. The structure of compound 16a was further elucidated by X-ray diffraction (Figure 2).

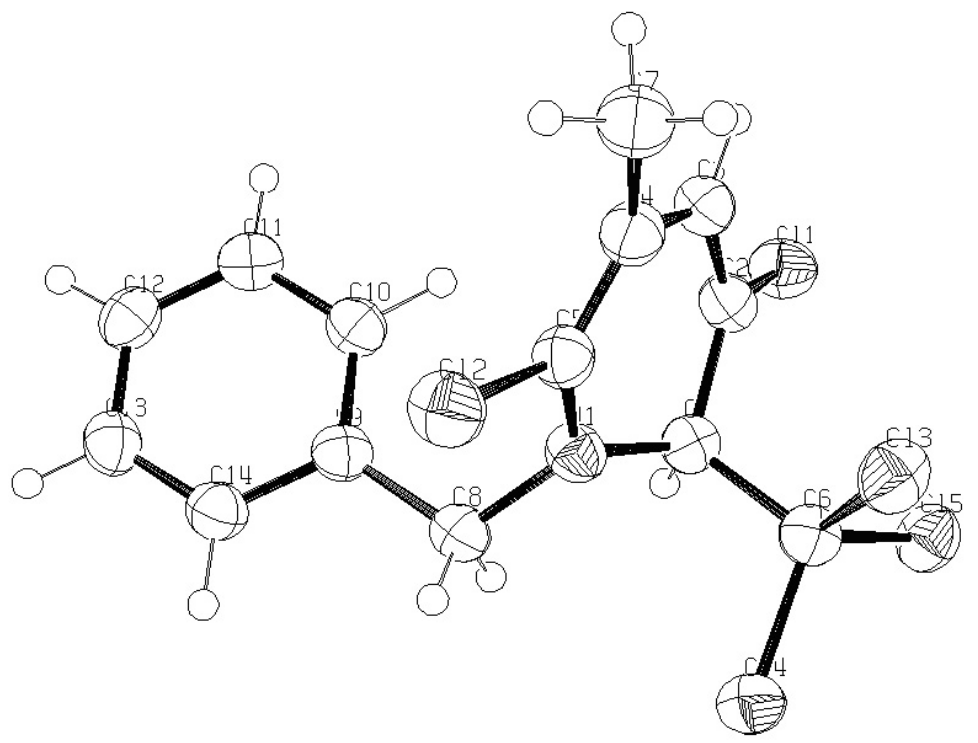

Figure 2. Perspective view of the X-ray crystal structure of $\mathbf{1 6 a}$. 


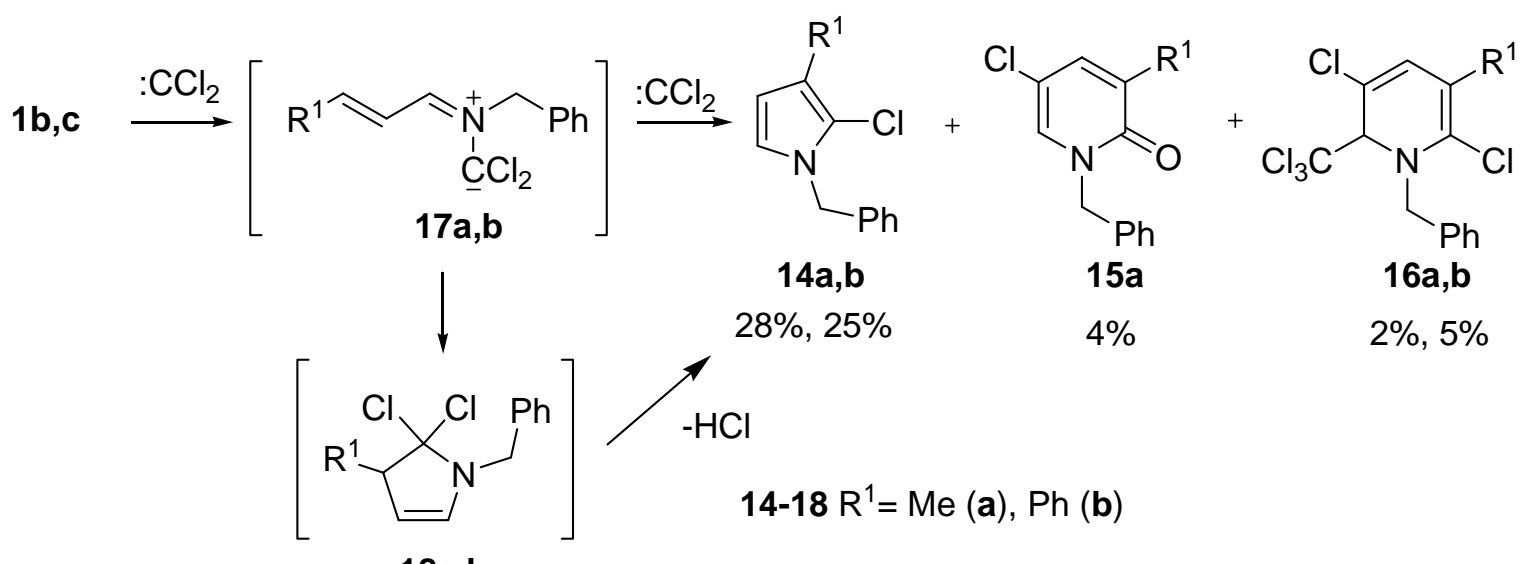

$18 \mathrm{a}, \mathrm{b}$

\section{Scheme 8}

Chloropyrroles 14a,b are formed via 1,5-cyclization of dichloroazomethine ylides $\mathbf{1 7 a}, \mathbf{b}$, arising by the reaction of the starting azadienes with dichlorocarbene, into dichloropyrrolines 18a,b, followed by dehydrochlorination. Pyridone 15a is likely to be formed by the following mechanism. An electrophilic dichlorocarbene readily adds to a nucleophilic enamine $\mathrm{C}=\mathrm{C}$ bond of pyrroline 18a to give cyclopropapyrrole 19a. Further, which is characteristic of aminosubstituted dichlorocyclopropanes, the three-membered ring undergoes cleavage by a bond opposite to the dichloromethylene group, yielding tetrahydropyridine derivative 20a (Scheme 9). Hydrolysis of the latter on silica during chromatographic treatment of the reaction mixture gives rise to pyridone 15a. Alternatively, the latter can arise via hydrolysis of salt 22a formed by dehydrochlorination of compound 20a. 


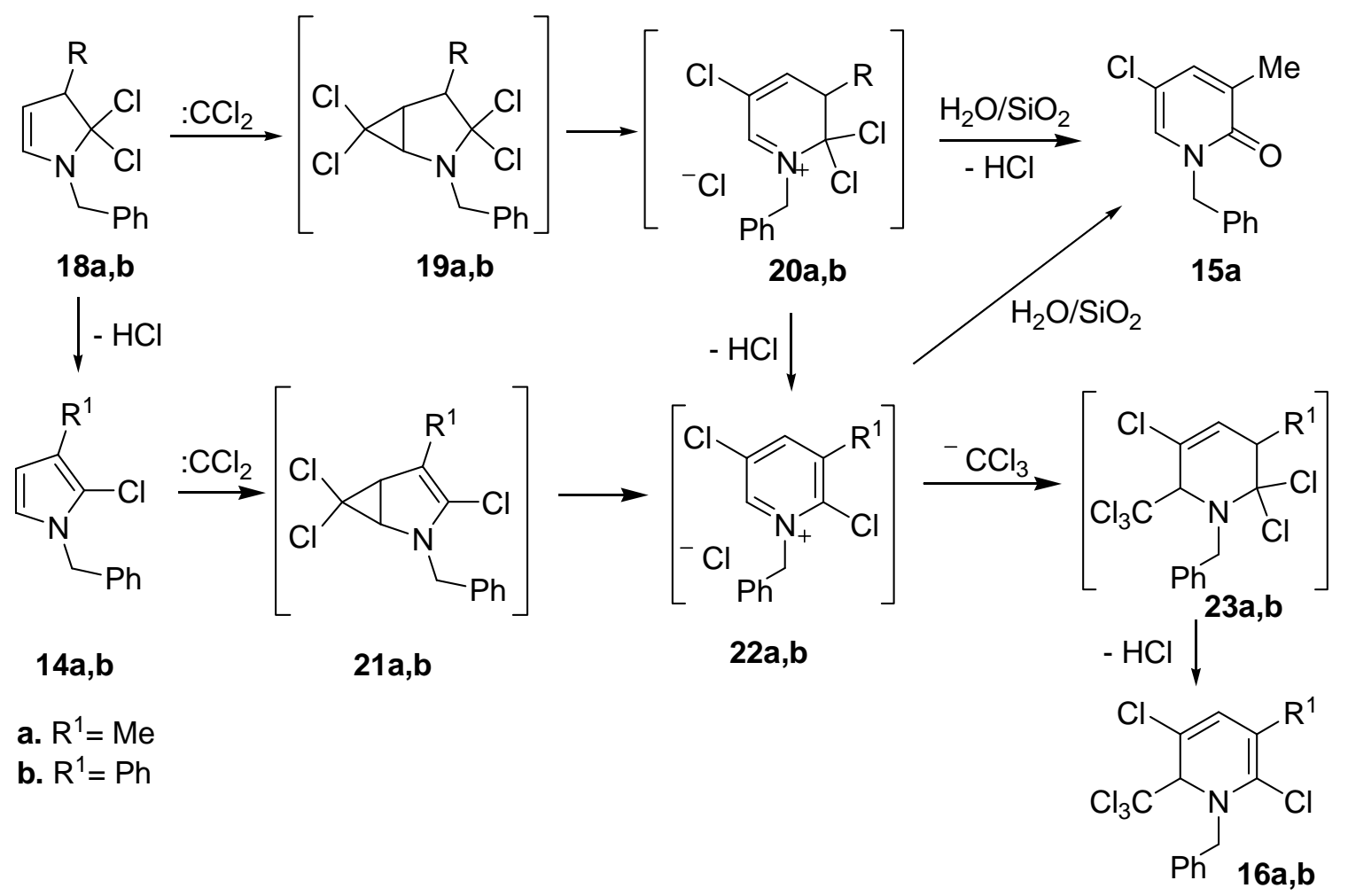

\section{Scheme 9}

The formation of dihydropyridines $\mathbf{1 6 a , b}$ may occur by two routes. The reaction of pyridinium salts 22a,b with trichloromethide gives compounds 23 a,b which hydrolyze on silica into compounds 16a,b. Pyridinium salts 22a,b may also be formed via a route involving cyclopropanation of the major reaction products pyrroles $\mathbf{1 4 a , b}$, leading to cyclopropapyrroles $\mathbf{2 1 a}, \mathbf{b}$, and cleavage of the three-membered ring by a bond opposite to the dichloromethylene group. Evidence for the possible formation of intermediates 21a,b was obtained in a separate experiment on the thermocatalytic decomposition of sodium trichloroacetate in the presence of pyrrole 14a, which resulted in the isolation of compound 16a in a low yield ( $c f^{1}{ }^{1}$ ). (Scheme 10).

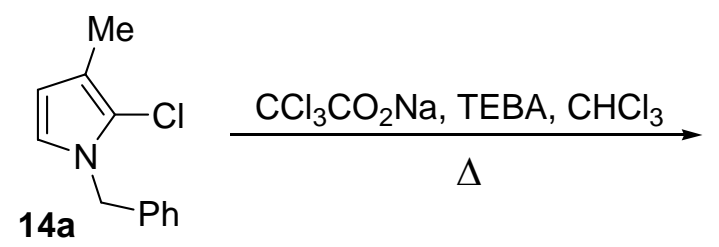<smiles>CC1=C(Cl)N(Cc2ccccc2)C(C(Cl)(Cl)Cl)C(Cl)=C1</smiles>

\section{Scheme 10}


Thus, dichloroylides $\mathbf{1 7 a} \mathbf{a}, \mathbf{b}$ formed by the reaction of azadienes $\mathbf{1 b}, \mathbf{c}$ with dichlorocarbene, unlike dichloroylide $\mathbf{8}$ from azadiene $\mathbf{1 a}$ and dichloroylide from azadiene $\mathbf{1 d}{ }^{3}$ undergo 1,5 rather than 1,3-cyclization.

To find out reasons for the different behavior of difluoro- and dichlorosubstituted azomethine ylides and reveal factors responsible for the preferential cyclization pathway, we performed computations of reaction profiles using the Gaussian suite of quantum-chemical programs. ${ }^{11}$ Geometry optimizations of intermediates, transition states, reactants, and products in the gas phase were performed at the B3LYP/6-31G* level. For the sake of simplicity, as models for approximation of the chemical behavior of ylides from azadienes 1a-d we took azadienes 23a-c, 24a-c, in view of the expectation that the phenyl groups eliminated on passing from 1a-d to 23a-c,24a-c would not strongly affect both 1,3- and 1,5-cyclization of the corresponding ylides. Energy parameters of the reactions shown in Scheme 11 were obtained.

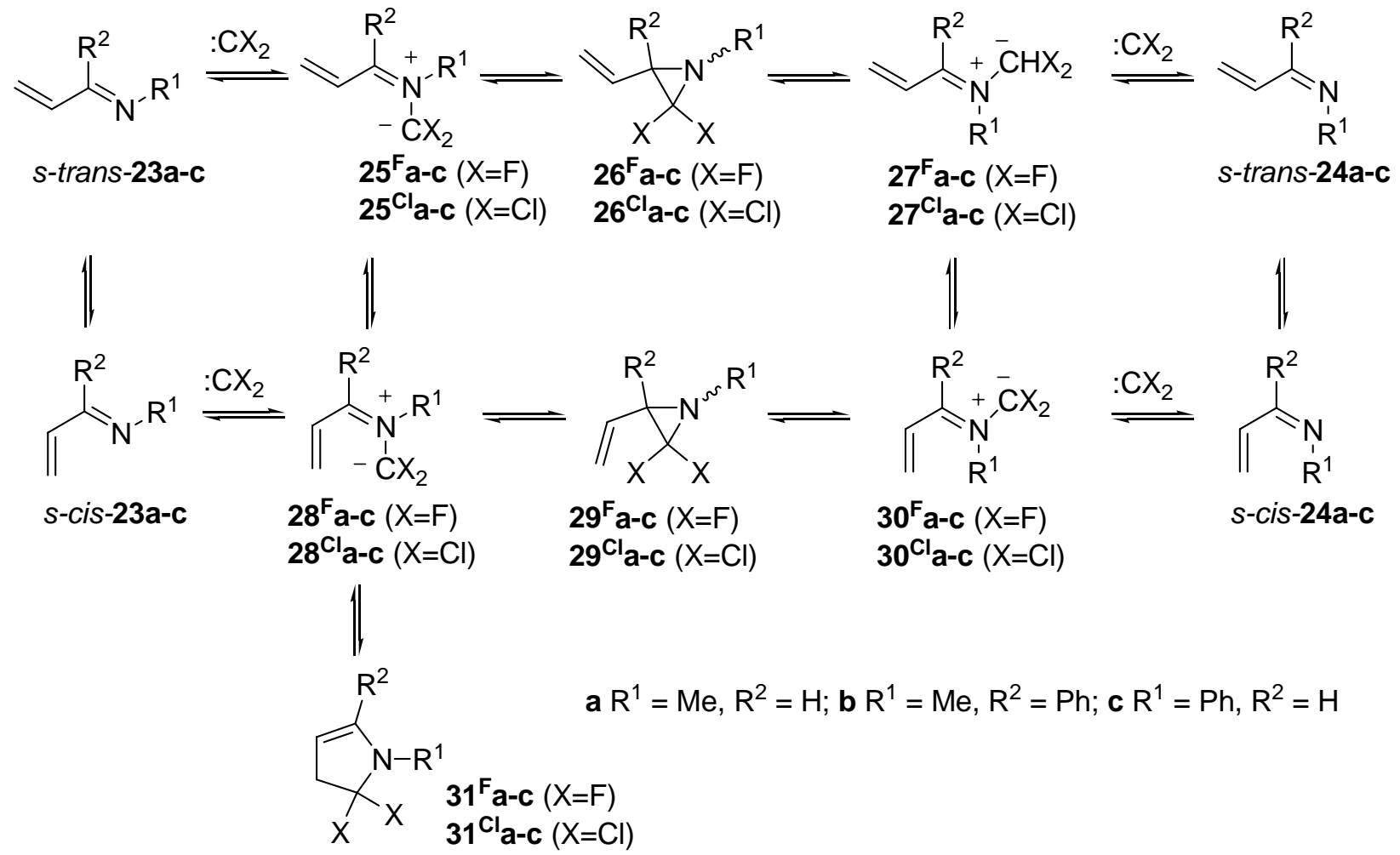

\section{Scheme 11}

According to the computation results, the most populated are ylides s-trans-23a-c (Figures 3, 8, 13). These results are consistent with the NMR spectra of 1-azabuta-1,3-dienes 1a-d. Compounds 1a-d were prepared by condensation of the corresponding aldehyde and amine. Therewith, a single $(E)$-isomer of azadienes $\mathbf{1 b}$-d and a mixture of the $(E)$ - and $(Z)$-isomers of azadiene 1a are formed. ${ }^{12}$ In the latter case, the major $(Z)$-isomer $1 \mathbf{a}$ was the only isolated in the crystalline state, and it was reacted with carbenes. 
The computation results are presented in Figures 3-15. The resulting data show that the barriers to the formation of difluorosubstituted azomethine ylides in the reactions of difluorocarbene with azadienes 23-24a-c are 6.4-12.4 $\mathrm{kcal} \mathrm{mol}^{-1}$, whereas the formation of dichlorosubstituted azomethine ylides in the reactions of dichlorocarbene with azadienes is barrierless. The lack of barriers to ylide formation in the case of dichlorocarbene is associated with the much higher energy of the latter, and is consistent with available reactivity data for these two species. Even if we assume that more advanced quantum-chemical approaches or an augmented basis set will reveal a low barrier (the fact that DFT B3LYP/6-31G(d) does not reveal this barrier suggests that it is very low), this by no means will affect conclusions given below. As follows from Figures 4-7, 9-12, 14, 15, there is a radical difference in the reactions of difluoroand dichlorocarbenes, leading to difluoro- and dichlorosubstituted azomethine ylides. This difference consists in that the barriers to 1,3-cyclizations leading to aziridines or 1,5-cyclizations leading to pyrrolines are always lower than the barriers to dissociation of these intermediates to the starting dichlorocarbene and azadiene, whereas the barriers to the corresponding cyclization reactions of difluorosubstituted azomethine ylides are mostly higher than the barriers to dissociation of these intermediates to the starting difluorocarbene and azadiene. In other words, dichlorocarbene reactions with azadienes are irreversible, whereas difluorocarbene reactions with azadienes are reversible.

Analysis of the computation results for the reaction of difluorocarbene with azadienes 23a, 24a shows that the barriers to the 1,3-cyclization of ylides $25^{\mathrm{F}} \mathrm{a}, 27^{\mathrm{F}} \mathrm{a}, 28^{\mathrm{F}} \mathrm{a}, 30^{\mathrm{F}} \mathrm{a}$ into the corresponding aziridines are higher than the barriers to dissociation of these intermediates into the starting materials. Pyrrole $\mathbf{3 1}{ }^{\mathbf{F}} \mathbf{a}$ can be formed only by 1,5-cyclization of ylide $\mathbf{2 8} \mathbf{F} \mathbf{a}$ which can result from either the reaction of difluorocarbene with azadiene $s$-cis-23a or $s$-trans $\rightarrow$-cisisomerization of ylide $25^{\mathbf{F}} \mathbf{a}$. Since azadiene $s$-trans-23a the most populated (Figure 3) and more reactive than azadiene $s$-cis-23a (Figure 4), ylide $\mathbf{2 5}^{\mathbf{F}} \mathbf{a}$ is preferentially formed. However, the latter prefers to dissociate rather than to izomerize into ylide $28^{\mathbf{F}} \mathbf{a}$. As a result, difluorocarbene is consumed in reactions whose barriers are lower than the barrier to the isomerization $25^{\mathbf{F}} \mathbf{a} \rightarrow$ $\mathbf{2 8}^{\mathbf{F}} \mathbf{a}$, equal to $10.5 \mathrm{kcal} \mathrm{mol}^{-1}$, for example, in dimerization leading to tetrafluoroethene. ${ }^{13}$ These computational results explain the absence of both 1,3- and 1,5-cyclization products in difluorocarbene reactions of azadienes $\mathbf{1 b}, \mathbf{c}$.

A different picture is observed in dichlorocarbene reactions. The reaction of dichlorocarbene with the most populated azadiene s-trans-23a (Figure 6) gives rise to ylide $25^{\mathrm{Cl}}$ a whose barrier to cyclization into aziridine $\mathbf{2 6}^{\mathrm{Cl}} \mathbf{a}\left(10.2 \mathrm{kcal} \mathrm{mol}^{-1}\right)$ is higher than the barrier to conversion into ylide $\mathbf{2 8}^{\mathrm{Cl}}$ a $\left(9.4 \mathrm{kcal} \mathrm{mol}^{-1}\right)$. The latter may also be formed by the reaction of dichlorocarbene with the second most populated azadiene $s$-cis-23a (Figure 6). Ylide $\mathbf{2 8}^{\mathrm{Cl}}$ a has a much lower barrier to 1,5-cyclization into pyrroline $31^{\mathrm{Cl}} \mathbf{a}\left(2.8 \mathrm{kcal} \mathrm{mol}^{-1}\right)$ than that to 1,3 -cyclization into aziridine $29^{\mathrm{Cl}} \mathbf{a}\left(14.2 \mathrm{kcal} \mathrm{mol}^{-1}\right)$. These data fit experimental results, namely, the formation of pyrrole derivatives $\mathbf{1 4 a}, \mathbf{b}$ and their subsequent reaction products, compounds $\mathbf{1 5 a}$ and $\mathbf{1 6 a}, \mathbf{b}$, in the reactions of dichlorocarbene with azadienes $\mathbf{1 b}, \mathbf{c}$. 


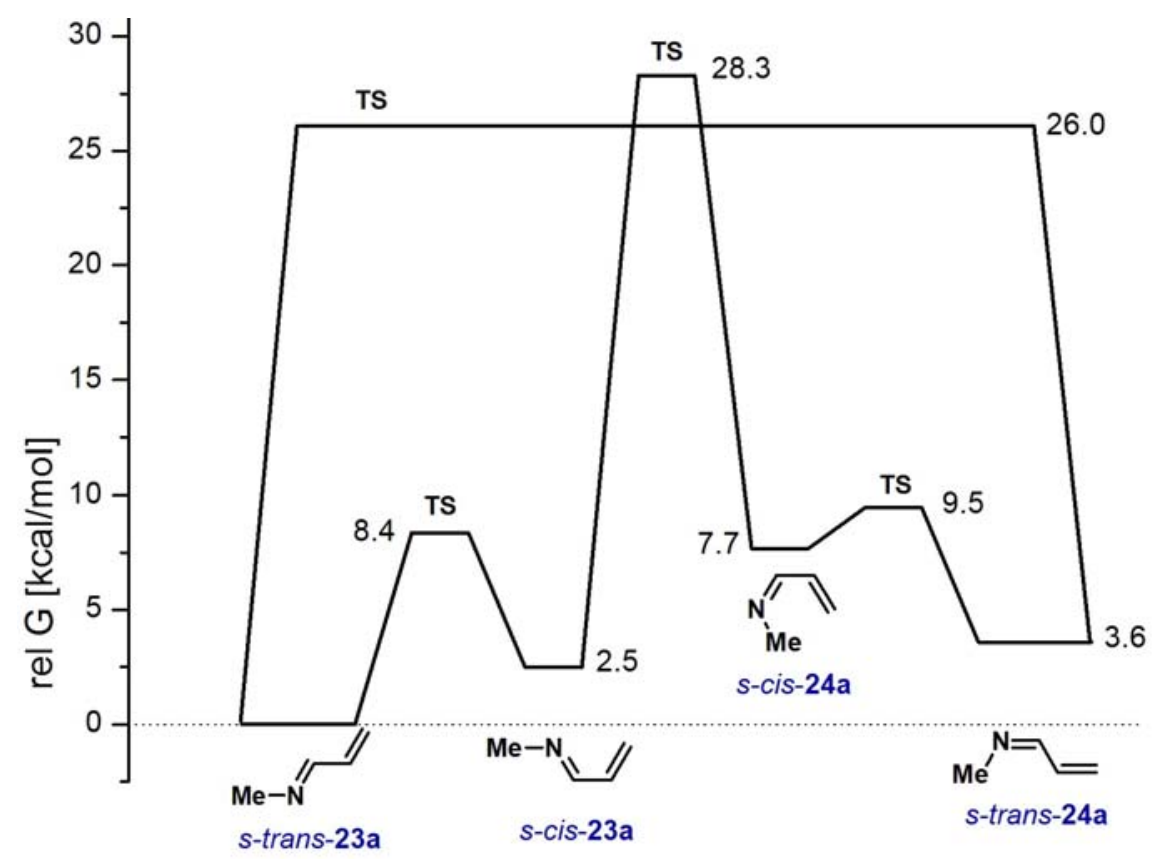

Figure 3. Free energy diagram for interconversion of $N$-methyl-1-azabuta-1,3-diene stereoisomers 23a, 24a. Free energies $\left[\mathrm{kcal} \mathrm{mol}^{-1}\right]$ computed at the B3LYP/6-31G* level. Energies are reported with respect to imine s-trans-23a.

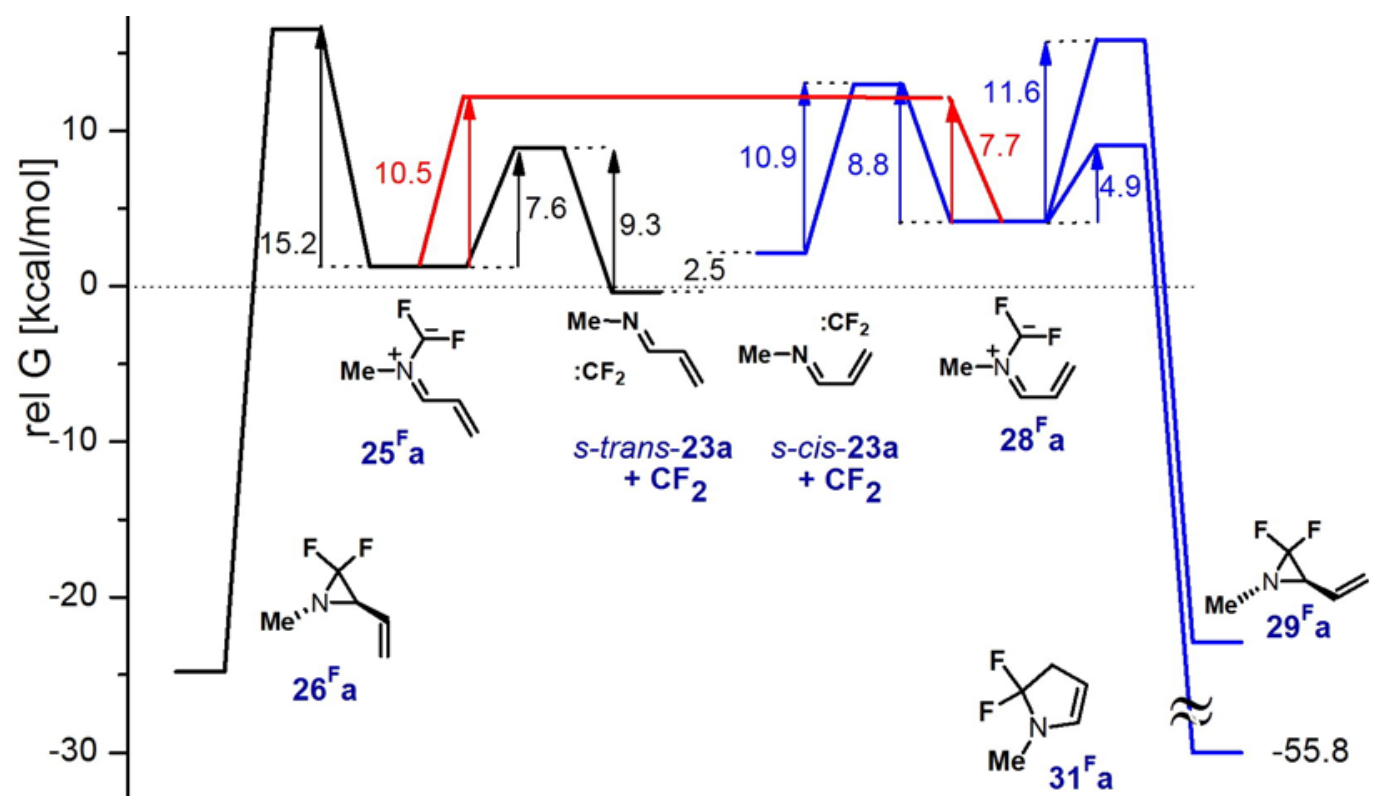

Figure 4. Reaction profiles for formation of difluoroazomethine ylides from s-cis- and s-trans$N$-methyl-1-azabuta-1,3-dienes $\mathbf{2 3} \mathbf{a}$ and interconversion of ylides $25^{\mathbf{F}} \mathbf{a}, \mathbf{2 8} \mathbf{F}$ a and their 1,3cyclization into aziridine $26^{\mathrm{F}}$ a and 1,5-cyclization into pyrroline $31^{\mathrm{F}} \mathrm{a}$. Free energies [kcal mol${ }^{-1}$ ] computed at the B3LYP/6-31G* level. Energies are reported with respect to ylide $27^{\mathbf{F}} \mathbf{a}$. 


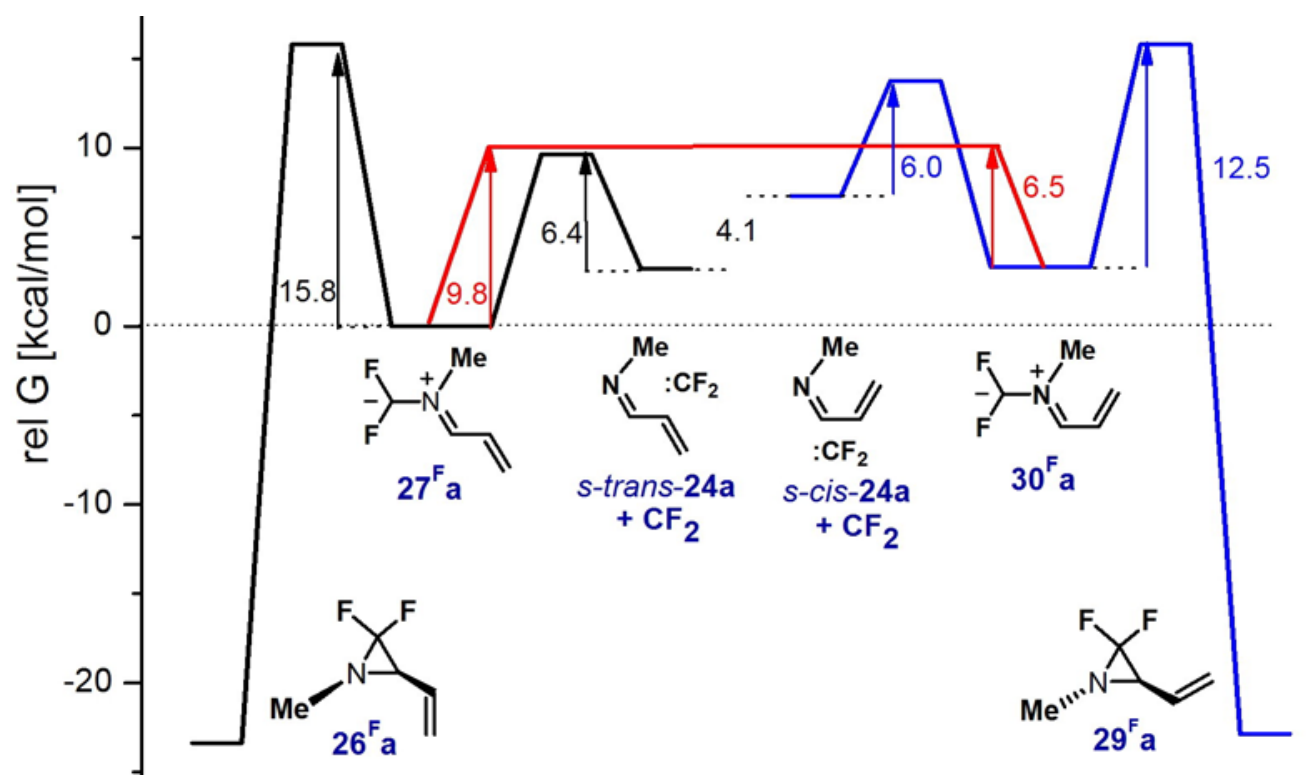

Figure 5. Reaction profiles for formation of difluoroazomethine ylides from s-cis- and s-trans$N$-methyl-1-azabuta-1,3-dienes $24 \mathbf{a}$ and interconversion of the ylides $27^{\mathrm{F}} \mathbf{a}, \mathbf{3 0}^{\mathrm{F}} \mathbf{a}$ and their 1,3cyclization into aziridines $26^{\mathbf{F}} \mathbf{a}, \mathbf{2 9} \mathbf{F}^{\mathrm{F}}$. Free energies [kcal mol ${ }^{-1}$ ] computed at the B3LYP/6-31G* level. Energies are reported with respect to ylide $27^{\mathrm{F}} \mathrm{a}$.

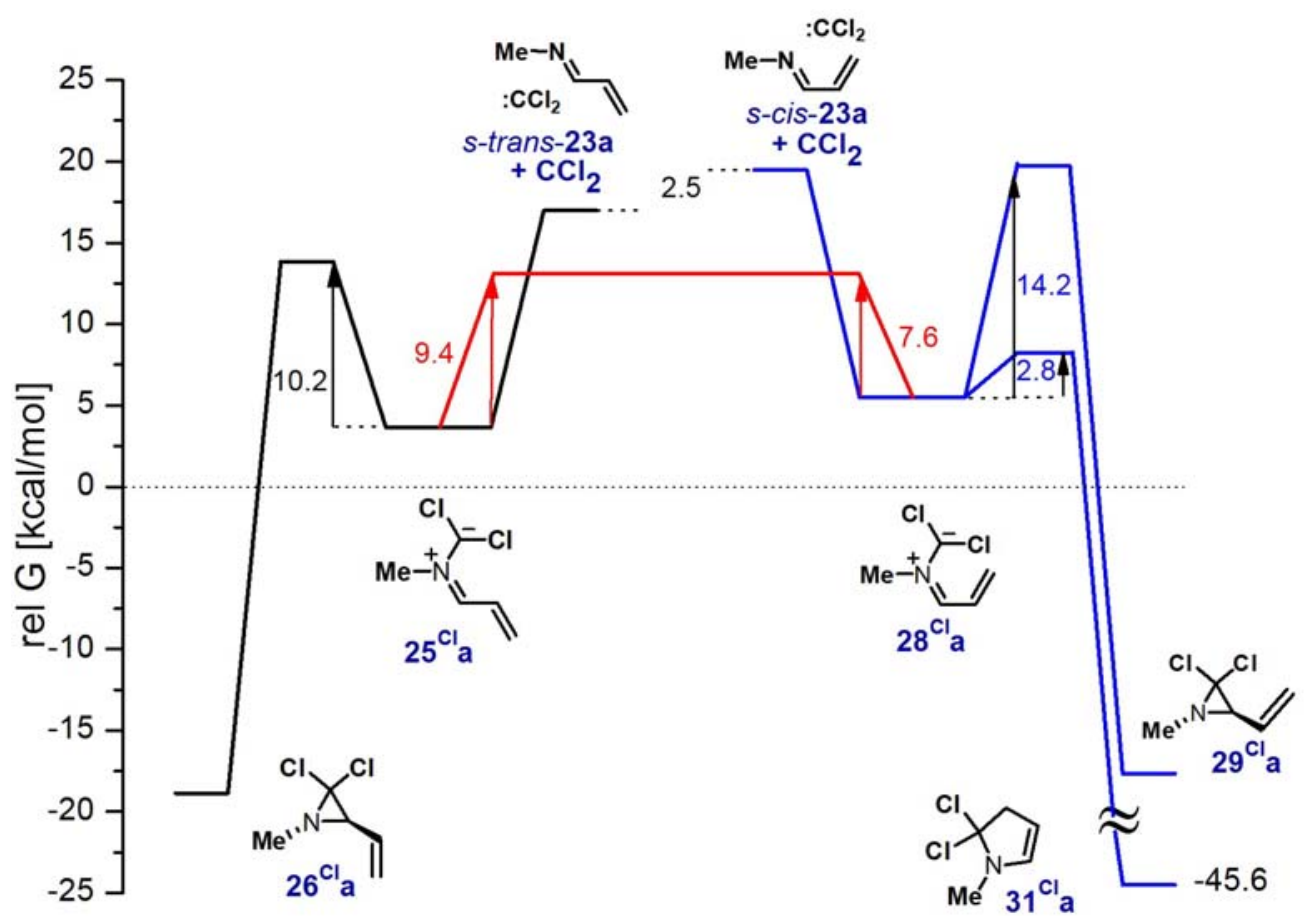

Figure 6. Reaction profiles for formation of dichloroazomethine ylides from s-cis- and s-trans$N$-methyl-1-azabuta-1,3-dienes $23 \mathbf{a}$ and interconversion of the ylides $25^{\mathrm{Cl}}$ a, $28^{\mathrm{Cl}}$ a and their 1,3cyclization into aziridine $26^{\mathrm{Cl}}$ a and 1,5-cyclization into pyrroline $31^{\mathrm{Cl}} \mathbf{a}$. Free energies [kcal mol ${ }^{-1}$ ] computed at the B3LYP/6-31G* level. Energies are reported with respect to ylide $27^{\mathrm{Cl}} \mathbf{a}$. 


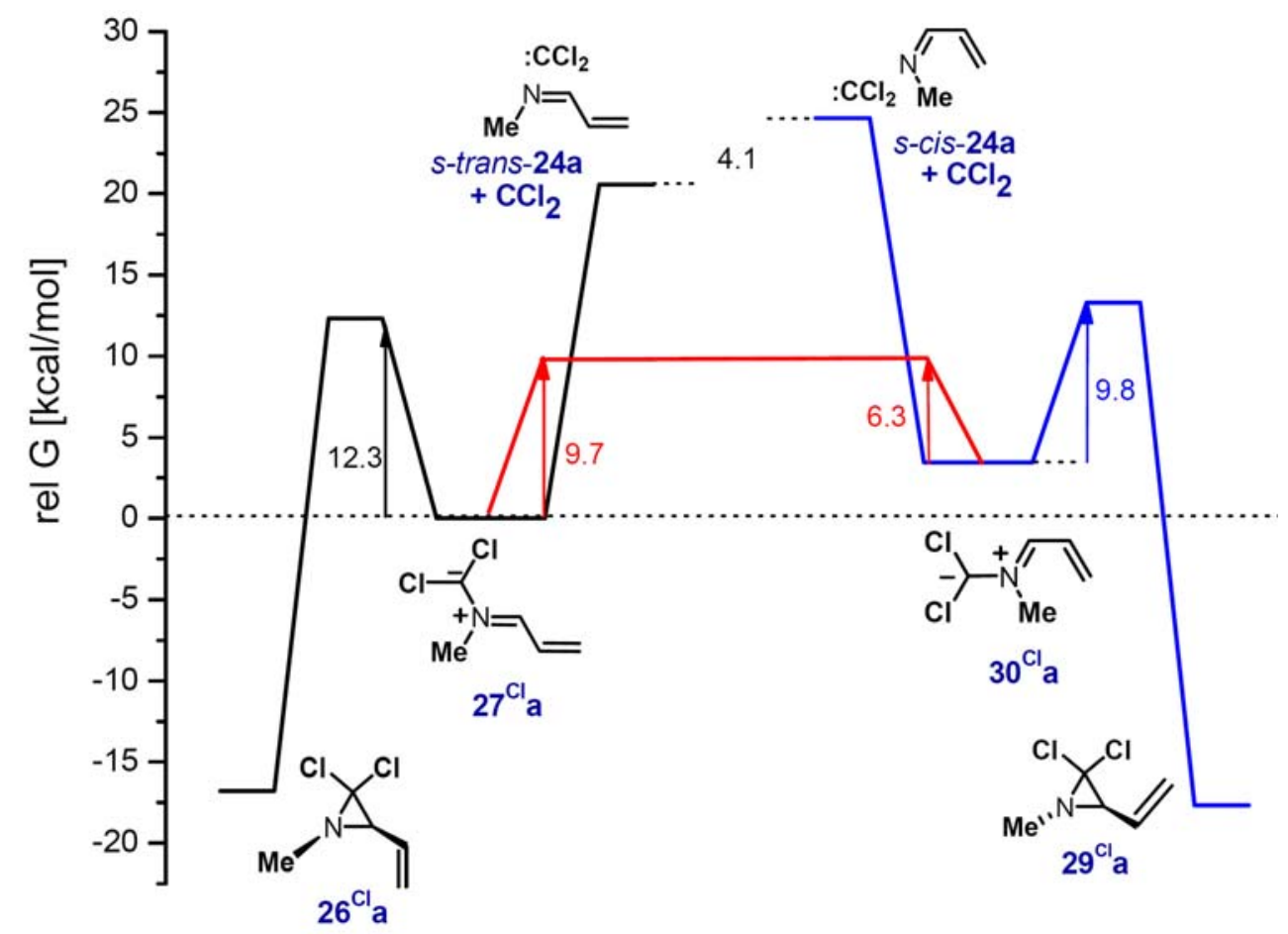

Figure 7. Reaction profiles for formation of dichloroazomethine ylides from s-cis- and s-trans$N$-methyl-1-azabuta-1,3-dienes $24 \mathbf{a}$ and interconversion of the ylides $27^{\mathrm{Cl}}$ a, $30^{\mathrm{Cl}} \mathbf{a}$ and their 1,3cyclization into aziridines $26^{\mathrm{Cl}}$ a, $\mathbf{2 9}^{\mathrm{Cl}}$ a. Free energies [kcal mol${ }^{-1}$ ] computed at the B3LYP/6$31 \mathrm{G}^{*}$ level. Energies are reported with respect to ylide $27^{\mathrm{Cl}} \mathbf{a}$.

2-Phenyl substitution in azadienes 23, 24 produces considerable changes in the energy characteristics of both their reactions with carbenes and reactions of the corresponding ylides. Moreover, an appreciable change in the relative population of azadienes themselves is observed (Figure 8). The reaction of difluorocarbene with the most populated azadiene s-trans-23b results in formation of ylide $\mathbf{2 5}^{\mathrm{F}} \mathbf{b}$ whose barrier to isomerization into ylide $\mathbf{2 8}^{\mathrm{F}} \mathbf{b}\left(6.6 \mathrm{kcal} \mathrm{mol}^{-1}\right)$ lower than the barrier to dissociation into the starting molecules $\left(7.1 \mathrm{kcal} \mathrm{mol}^{-1}\right)$ and 1,3-cyclization into aziridine $\mathbf{2 6}^{\mathrm{F}} \mathbf{b}\left(7.8 \mathrm{kcal} \mathrm{mol}^{-1}\right.$ ) (Figure 9). Ylide $\mathbf{2 8}^{\mathrm{F}} \mathbf{b}$ has a low barrier to 1,5-cyclization into pyrroline $31^{\mathrm{F}} \mathbf{b}\left(4.3 \mathrm{kcal} \mathrm{mol}^{-1}\right)$, which is much lower than the barrier to its dissociation into the starting azadiene and difluorocarbene $\left(10.5 \mathrm{kcal} \mathrm{mol}^{-1}\right)$ (Figure 9). By contrast, the barriers to dissociation of ylide $27^{\mathrm{F}} \mathbf{b}, \mathbf{3 0} \mathbf{F}^{\mathrm{F}} \mathbf{b}$ is lower than the barriers to their 1,3-cyclization into aziridines $\mathbf{2 6}^{\mathrm{F}} \mathbf{b}, \mathbf{2 9}{ }^{\mathrm{F}} \mathbf{b}$ (Figure 10). Thus, the fact that we obtained pyrrole $\mathbf{2}$ in the reaction of azadiene 1a with difluorocarbene completely agrees with computation results, and the formation of this product is most likely to occur via addition of difluorocarbene to s-trans-azadiene 1a, isomerization of s-trans-isomer ylide $\mathbf{2 a}$ to $s$-cis-isomer, and cyclization of the latter. 


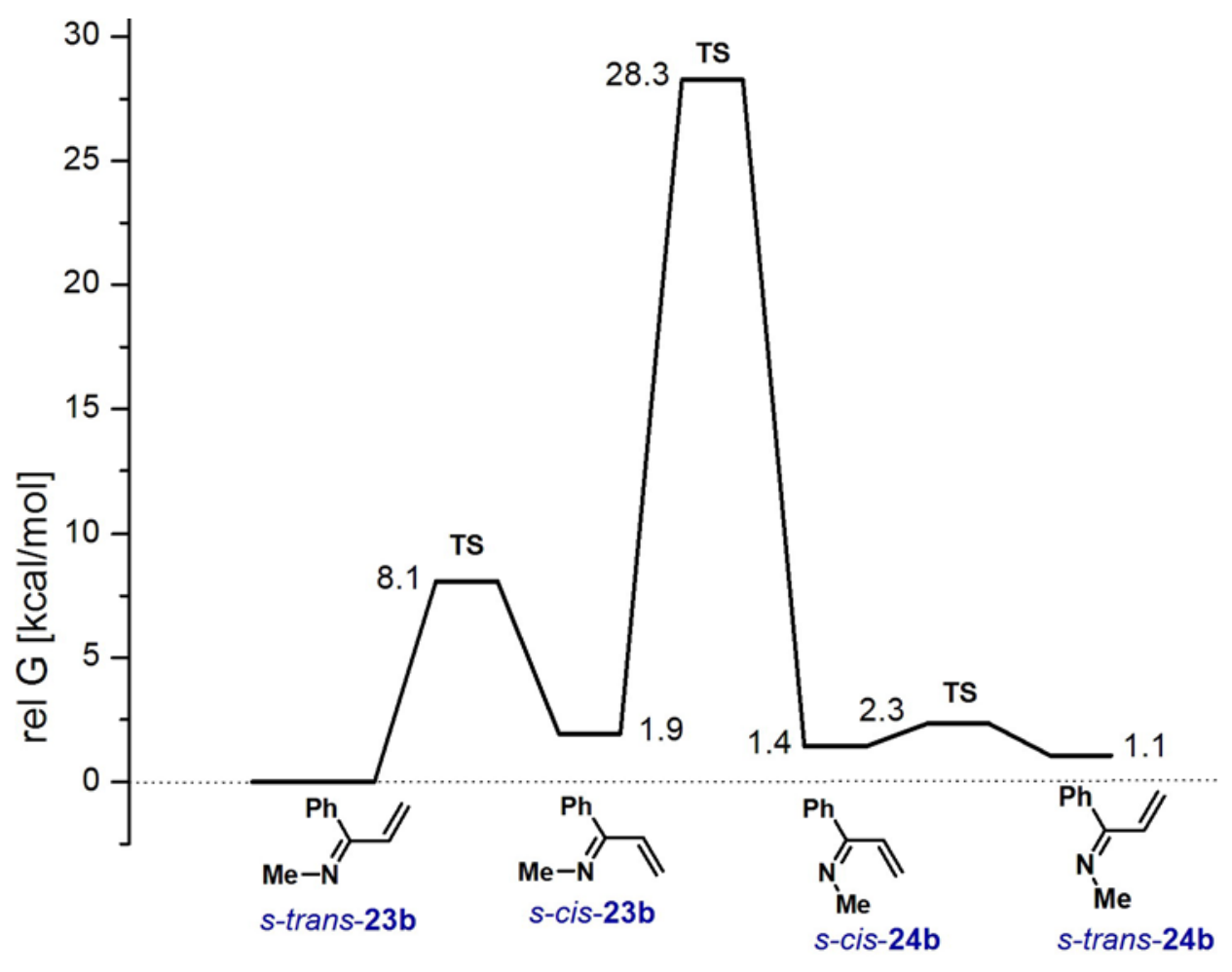

Figure 8. Free energy diagram for interconversion of stereoisomers of $N$-methyl-1-azabuta-1,3diene 23b, 24b. Free energies [ $\mathrm{kcal} \mathrm{mol}^{-1}$ ] computed at the B3LYP/6-31G* level. Energies are reported with respect to imine $s$-trans-23b.

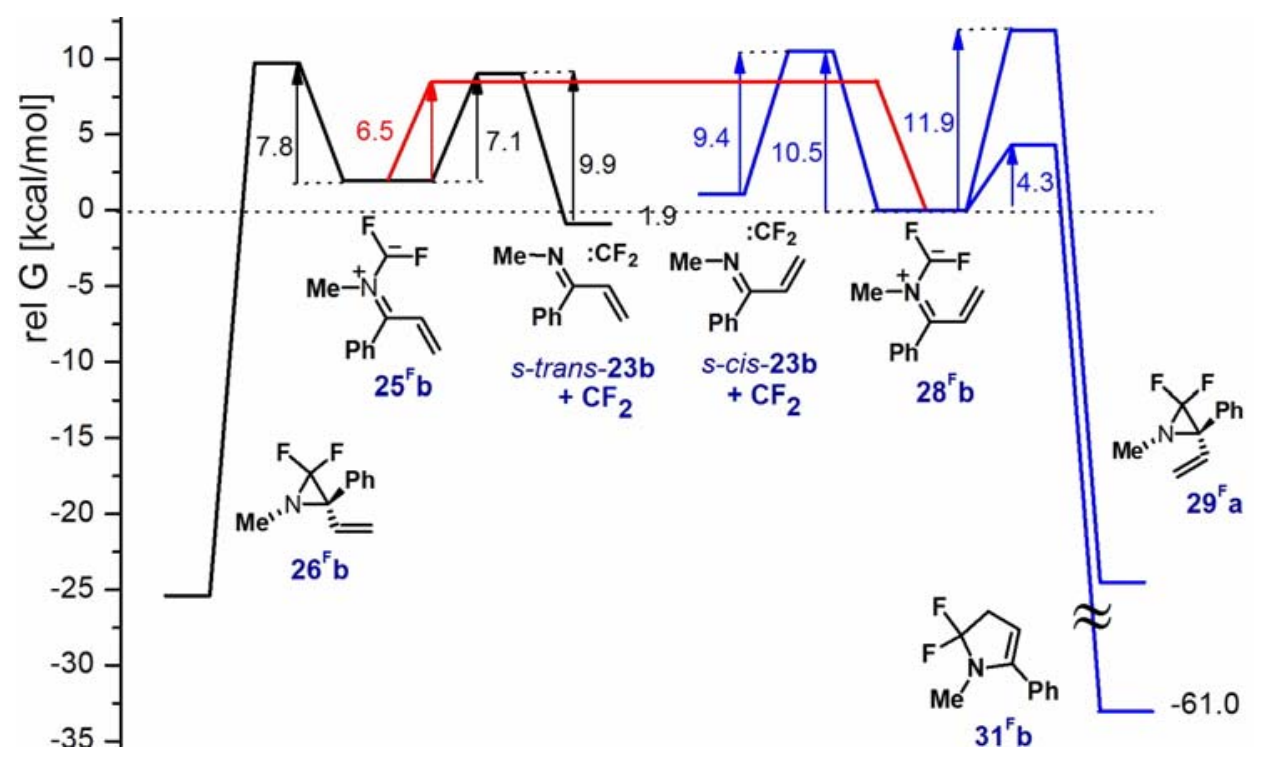

Figure 9. Reaction profiles for formation of difluoroazomethine ylides from s-cis- and s-trans$N$-methyl-1-azabuta-1,3-dienes $\mathbf{2 3 b}$ and interconversion of the ylides $\mathbf{2 5}^{\mathbf{F}} \mathbf{b}, \mathbf{2 8}^{\mathbf{F}} \mathbf{b}$ and their 1,3cyclization into aziridine $26^{\mathbf{F}} \mathbf{b}, \mathbf{2 9}^{\mathbf{F}} \mathbf{b}$ and 1,5-cyclization into pyrroline $31^{\mathbf{F}} \mathbf{b}$. Free energies [kcal $\mathrm{mol}^{-1}$ ] computed at the B3LYP/6-31G* level. Energies are reported with respect to ylide $\mathbf{2 8} \mathbf{F}^{\mathbf{F}} \mathbf{b}$. 


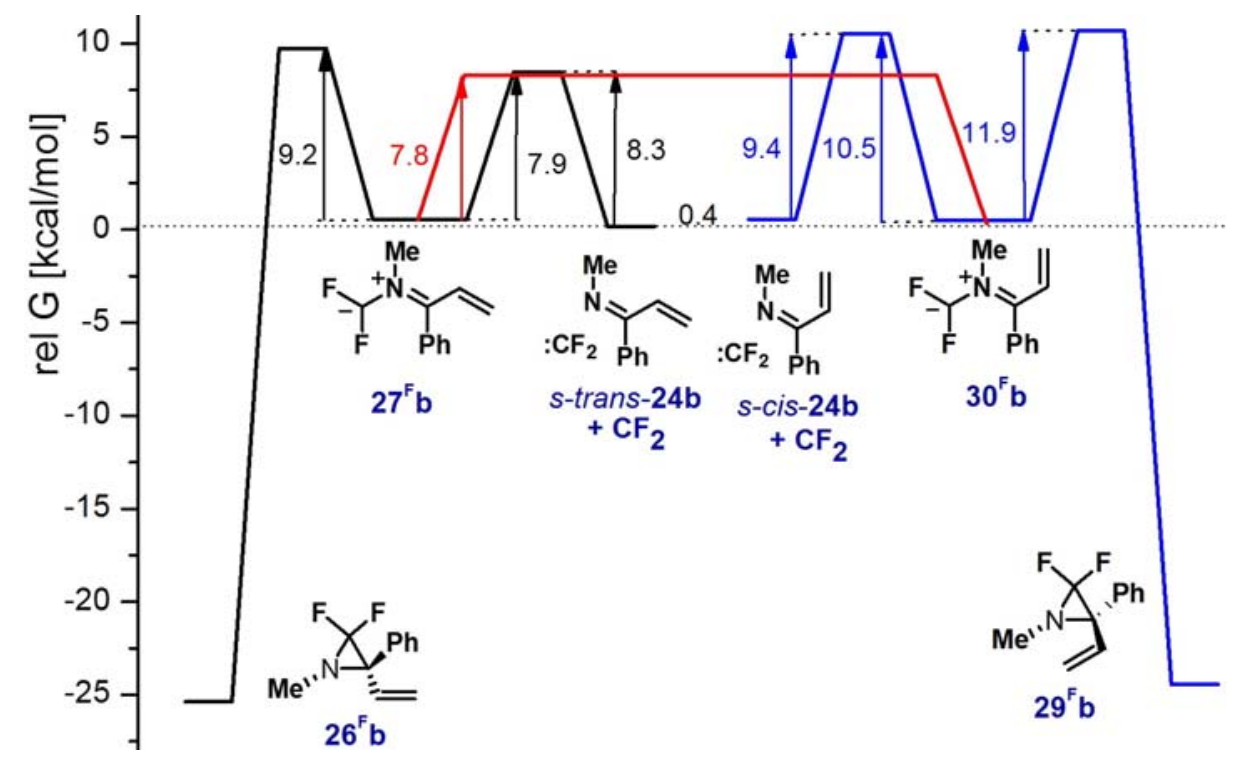

Figure 10. Reaction profiles for formation of difluoroazomethine ylides from s-cis- and s-trans$N$-methyl-1-azabuta-1,3-dienes $\mathbf{2 4 b}$ and interconversion of the ylides $27^{\mathbf{F}} \mathbf{b}, \mathbf{3 0}^{\mathbf{F}} \mathbf{b}$ and their 1,3cyclization into aziridine $\mathbf{2 6}^{\mathrm{F}} \mathbf{b}, \mathbf{2 9}^{\mathrm{F}} \mathbf{b}$. Free energies $\left[\mathrm{kcal} \mathrm{mol}^{-1}\right]$ computed at the B3LYP/6-31G* level. Energies are reported with respect to ylide $\mathbf{2 8}^{\mathrm{F}} \mathbf{b}$.

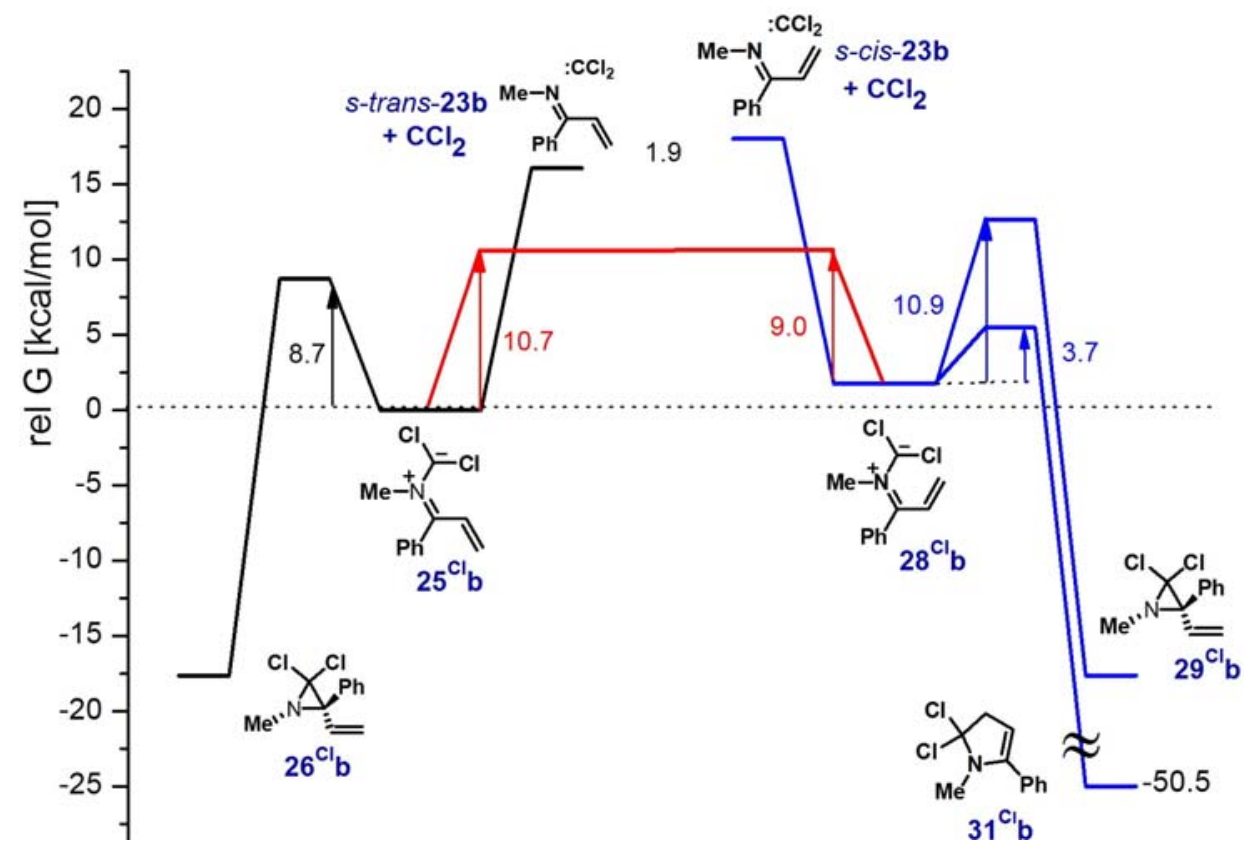

Figure 11. Reaction profiles for formation of dichloroazomethine ylides from s-cis- and s-trans$N$-methyl-1-azabuta-1,3-dienes $\mathbf{2 3} \mathbf{b}$ and interconversion of the ylides $25^{\mathrm{Cl}} \mathbf{b}, \mathbf{2 8}^{\mathrm{Cl}} \mathbf{b}$ and their 1,3cyclization into aziridine $26^{\mathrm{Cl}} \mathbf{b}, \mathbf{2 9}^{\mathrm{Cl}} \mathbf{b}$ and 1,5 -cyclization into pyrroline $31^{\mathrm{Cl}} \mathbf{b}$. Free energies $\left[\mathrm{kcal} \mathrm{mol}^{-1}\right]$ computed at the B3LYP/6-31G* level. Energies are reported with respect to ylide $25^{\mathrm{Cl}} \mathrm{b}$. 
The computation results for model reactions of dichlorosubstituted azomethine ylides $25^{\mathrm{Cl}} \mathbf{b}$, ${ }_{27}{ }^{\mathrm{Cl}} \mathbf{b} 28^{\mathrm{Cl}} \mathbf{b}, \mathbf{3 0}^{\mathrm{Cl}} \mathbf{b}$ (Figures 11, 12) fit the experiment in which compound 7 was obtained, via intermediate formation of aziridine $\mathbf{9}$, in the reaction of dichlorocarbene with azadiene 1a. Thus, 2-phenyl substitution in azadienes $\mathbf{2 3}, \mathbf{2 4}$ makes the barriers to 1,3-cyclization of ylides $25^{\mathrm{Cl}} \mathbf{b}$, $\mathbf{2 7}^{\mathrm{Cl}} \mathbf{b} \mathbf{2 8}{ }^{\mathrm{Cl}} \mathbf{b}, \mathbf{3 0}^{\mathrm{Cl}} \mathbf{b}$ into aziridines (Figures 11,12 ) lower compared to ylides $25^{\mathrm{Cl}} \mathbf{a}, \mathbf{2 7}^{\mathrm{Cl}}$ a $28^{\mathrm{Cl}}$ a, $\mathbf{3 0}^{\mathrm{Cl}}$ a (Figures 6,7) containing no phenyl substituent. The most favorable way of stabilization of dichloroylides $25^{\mathrm{Cl}} \mathbf{b}, 27^{\mathrm{Cl}} \mathbf{b}, \mathbf{3 0} \mathrm{Cl}^{\mathrm{Cl}} \mathbf{b}$ formed by dichlorocarbene reactions with the most populated azadienes s-trans-23b, s-trans-24b, s-cis-24b is cyclization into aziridine (Figures 11, 12). Therewith, the ylide formed from dichlorocarbene and the most populated azadiene s-trans-23b (Figure 8) has a lowed barrier to 1,3-cyclization into aziridine $\mathbf{2 6}^{\mathrm{Cl}} \mathbf{b}$ than the barrier to isomerization into ylide $\mathbf{2 8}^{\mathrm{Cl}} \mathbf{b}$ which can undergo 1,5 -cyclization into pyrroline $\mathbf{3 1}^{\mathrm{Cl}} \mathbf{b}$ (Figure $11)$.

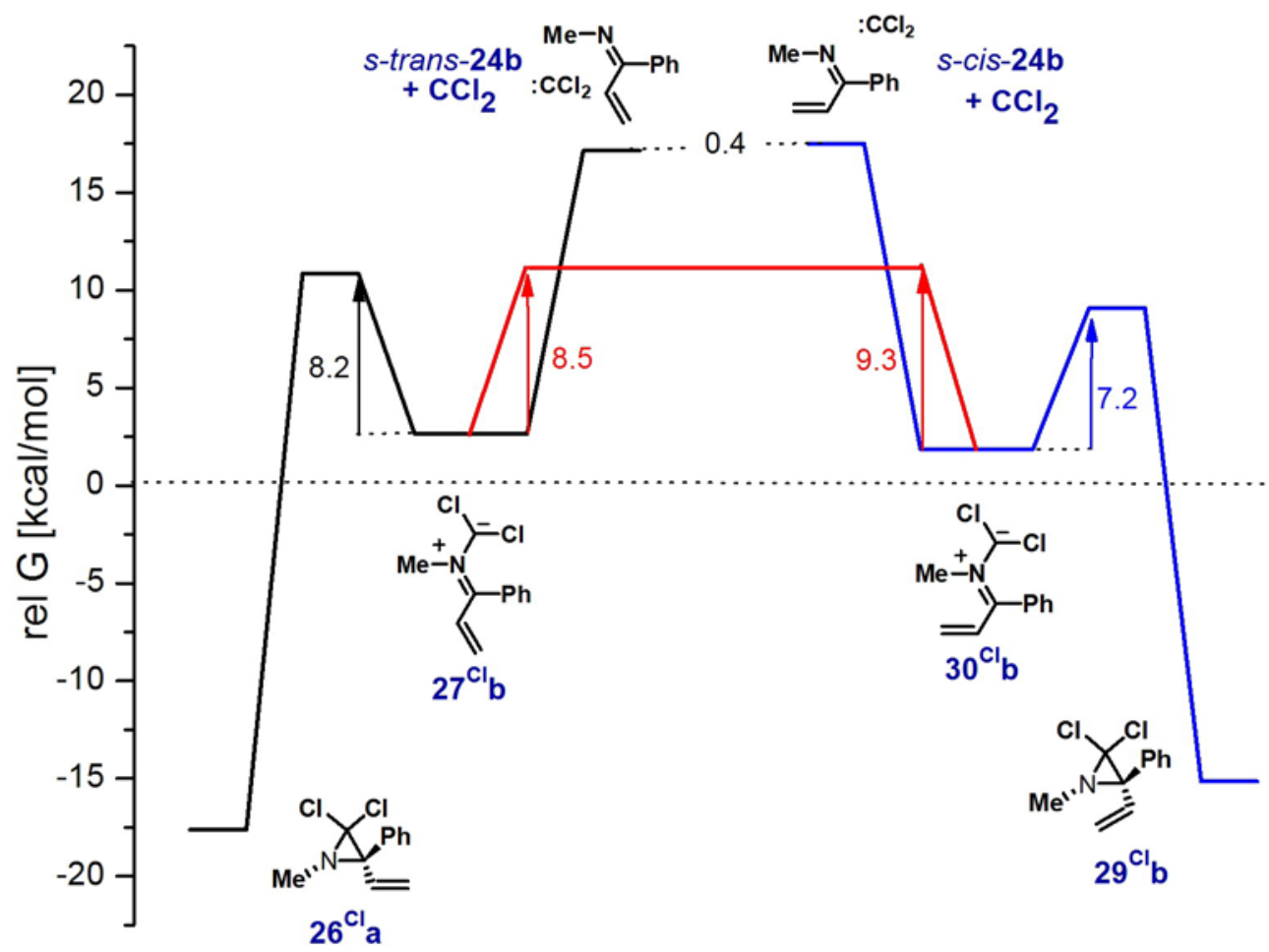

Figure 12. Reaction profiles for formation of difluoroazomethine ylides from s-cis- and s-trans$N$-methyl-1-azabuta-1,3-dienes $\mathbf{2 4 b}$ and interconversion of the ylides ylides $27^{\mathrm{Cl}} \mathbf{b}, \mathbf{3 0}^{\mathrm{Cl}} \mathbf{b}$ and their 1,3-cyclization into aziridine $\mathbf{2 6}^{\mathrm{Cl}} \mathbf{b}, \mathbf{2 9}^{\mathrm{Cl}} \mathbf{b}$. Free energies $\left[\mathrm{kcal} \mathrm{mol}{ }^{-1}\right.$ ] computed at the B3LYP/6-31G* level. Energies are reported with respect to ylide $\mathbf{2 5}^{\mathbf{C l}} \mathbf{b}$.

In going from $N$-methylazadienes 23a, 24a to $N$-phenylazadienes 23c, 24c, the relative stability of azadiene isomers changes only slightly, but the energy profiles for formation and reactions of the corresponding difluoro- and dichloroylides are affected considerably (Figures 3, 13-15). The reaction of difluorocarbene with the most populated azadiene s-trans-23c (Figure 
13) gives rise to ylide $25^{\mathrm{F}} \mathbf{c}$. Compared to ylide $25^{\mathrm{F}} \mathbf{b}$, ylide $25^{\mathrm{F}} \mathbf{c}$ has a lower barrier to 1,3 cyclization into aziridine and higher barrier to transformation into ylide $28^{\mathrm{F}} \mathbf{c}$ which might further transform into pyrroline $31^{\mathrm{F}} \mathbf{c}$ (Figure 14). Therewith, the barrier to dissociation into the starting molecules decreases and becomes lower by $5.2 \mathrm{kcal} \mathrm{mol}^{-1}$ lower than the barrier to 1,3cyclization into aziridine. As a result, difluorocarbene is consumed in side reactions with barriers lower than $11.9 \mathrm{kcal} \mathrm{mol}^{-1}$. These results explain the absence of both 1,3- and 1,5-cyclization products in the reaction of difluorocarbene with azadiene $\mathbf{1 d}$.

In the reaction of this azadiene with dichlorocarbene, replacement of the $N$-methyl substituents by $N$-phenyl, too, decreases the barrier to 1,3-cyclization into aziridine and increases the barrier of the isomerization $27^{\mathrm{Cl}} \mathbf{c} \rightarrow \mathbf{2 8}^{\mathrm{Cl}} \mathbf{c}$ (Figure 15). Therewith, the barrier to 1,3cyclization of ylide $27^{\mathrm{Cl}} \mathbf{c}$ turns to be $4.9 \mathrm{kcal} \mathrm{mol}^{-1}$ lower than the barrier to isomerization into ylide $28^{\mathrm{Cl}} \mathbf{c}$ which might further transform into pyrrolidine $30^{\mathrm{Cl}} \mathbf{c}$. There results are consistent with experimental data, ${ }^{3}$ namely, the formation of dichloroaziridine from azadiene $\mathbf{1 d}$ in the reaction with dichlorocarbene and the absence of the corresponding pyrrole derivatives from the reaction products.

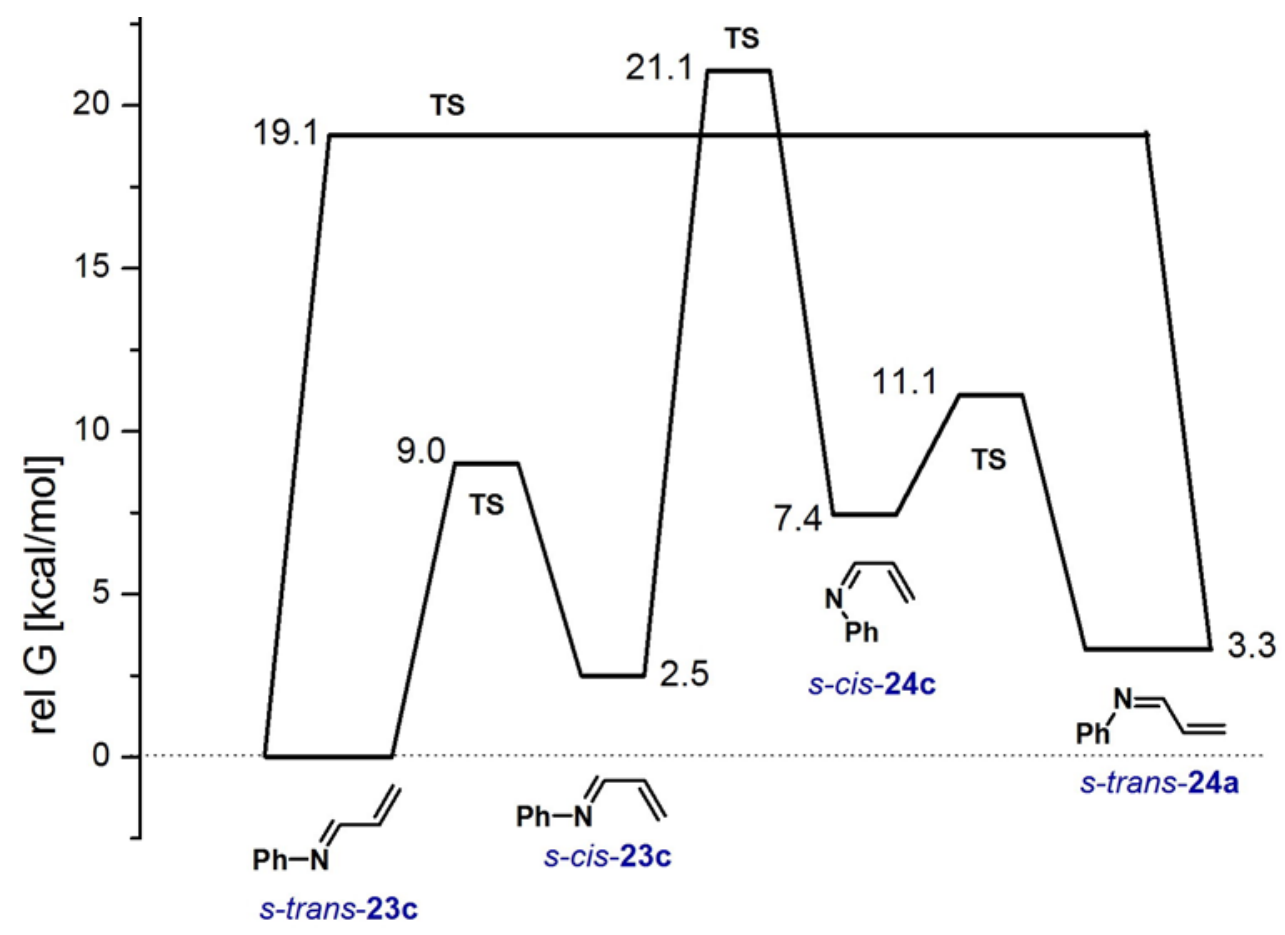

Figure 13. Free energy diagram for interconversion of stereoisomers of $N$-phenyl-1-azabuta-1,3diene 23c, 24c. Free energies $\left[\mathrm{kcal} \mathrm{mol}^{-1}\right]$ computed at the B3LYP/6-31G* level. Energies are reported with respect to imine s-trans-23c. 


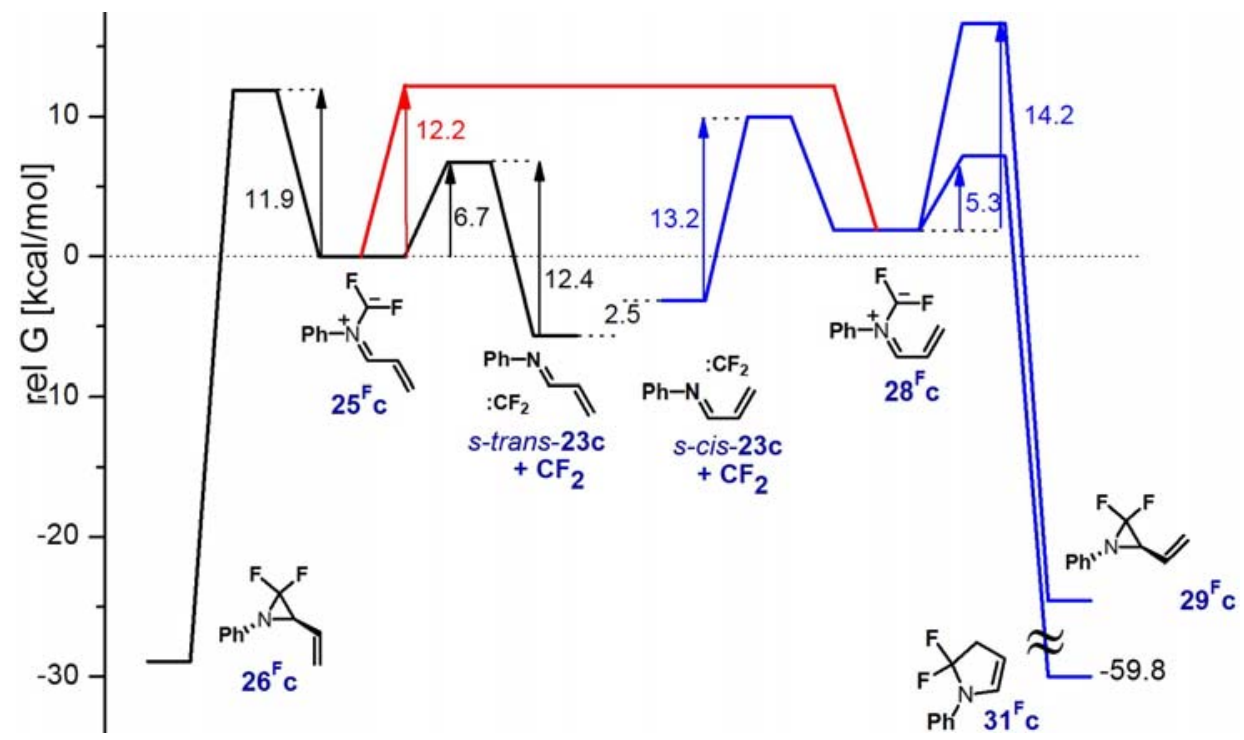

Figure 14. Reaction profiles for formation of difluoroazomethine ylides from s-trans- and s-cis$N$-phenyl-1-azabuta-1,3-dienes $\mathbf{2 3 c}$ and interconversion of the ylides $\mathbf{2 5}^{\mathbf{F}} \mathbf{c}, \mathbf{2 8}^{\mathbf{F}} \mathbf{c}$ and their 1,3cyclization into aziridine $26^{\mathrm{F}} \mathbf{c}, \mathbf{2 9}^{\mathrm{F}} \mathrm{c}$ and 1,5 -cyclization into pyrroline $31^{\mathrm{F}} \mathbf{c}$. Free energies [kcal $\mathrm{mol}^{-1}$ ] computed at the B3LYP/6-31G* level. Energies are reported with respect to ylides $\mathbf{2 5}^{\mathbf{F}} \mathbf{c}$.

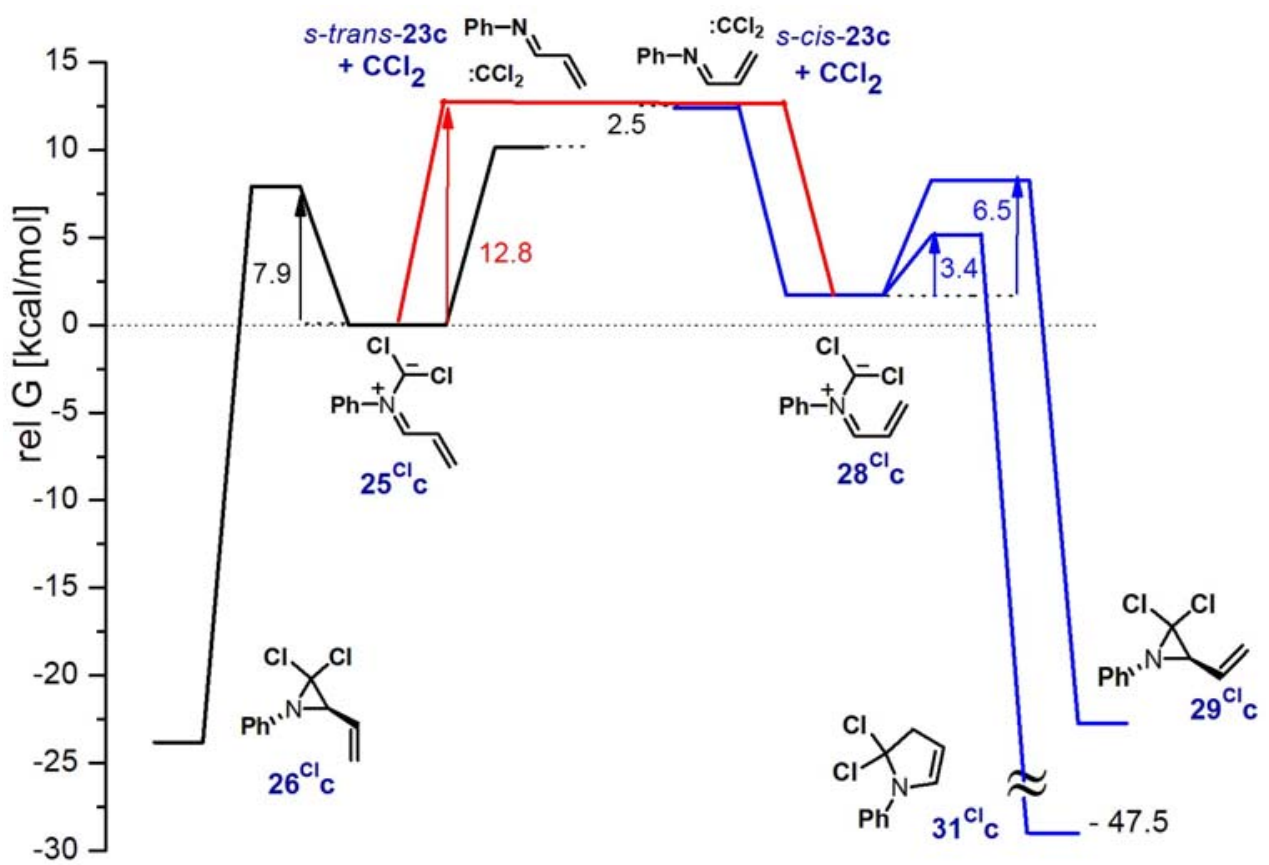

Figure 15. Reaction profiles for formation of difluoroazomethine ylides from $s$-trans- and $s$-cis$N$-phenyl-1-azabuta-1,3-dienes $23 \mathbf{c}$ and interconversion of the ylides $\mathbf{2 5}^{\mathrm{Cl}} \mathbf{c}, \mathbf{2 8}^{\mathrm{Cl}} \mathbf{c}$ and their 1,3 cyclization into aziridine ${ }^{26}{ }^{\mathrm{Cl}} \mathbf{c}, 2^{\mathrm{Cl}} \mathbf{c}$ and 1,5 -cyclization into pyrroline $3^{\mathrm{Cl}} \mathbf{c}$. Free energies $\left[\mathrm{kcal} \mathrm{mol}{ }^{-1}\right]$ computed at the B3LYP/6-31G* level. Energies are reported with respect to ylides $25^{\mathrm{Cl}} \mathrm{c}$. 
Thus, our experiments gave evidence to show that the reactions of 1-azabuta-1,3-dienes with difluoro- and dichlorocarbenes are quite sensitive to substituents in the azadiene and to the nature of the halogen. As follows from computations, the reactions of dichlorocarbene with azadienes are generally irreversible, whereas the reactions of difluorocarbene with azadienes are reversible. Reaction result is also strongly dependent on the geometry of the azadiene, since it predetermines the geometry of the primary azomethine ylide intermediate. Kinetic ylides formed from the most stable s-trans-azadienes are incapable to 1,5-cyclization into pyrrolines, and the latter can arise exclusively via $s$-trans $\rightarrow s$-cis-isomerization of the primary ylide. As shown by computations and experiments, this process is made possible by a certain structural modification of the ylide, i.e. introduction of substituents. With difluoroylides whose 1,3-cyclization is unfavored by energy and does not compete with other processes, the $s$-trans-ylide $\rightarrow s$-cis-ylide isomerization is facilitated by introduction of a bulky $(\mathrm{Ph})$ substituent in the 2-position of the parent azadiene. By contrast, with dichloroylides the $s$-trans $\rightarrow s$-cis isomerization leading eventually to pyrroline formation is realized only in the absence of $\mathrm{Ph}$ substituents in the 1 and 2 positions. Phenyl substitution in one of these positions produces such a strong decrease in the 1,3-cyclization barrier that aziridine formation becomes the major reaction. The observed difference in the effects of substituents in the azadiene on the structure and behavior of difluoroand dichloroylides is associated not only with the difference in the van der Waals radii of chlorine and fluorine, but also with the pyramidalization of the $\mathrm{NCHlg}_{2}$ fragment on replacement of chlorine by the more electronegative fluorine.

Comparison of the experimental and computational results for dihalocarbene reactions with azadienes leads us to conclude that DFT methods at the simple B3LYP/6-31G* level of theory which allows profound computations without severe simplification of real structures can be used for selecting substrates for purposeful synthesis of 1,3- or 1,5-cyclization products.

\section{Experimental Section}

General Procedures. The melting points were determined on a Boetius melting point apparatus (uncorrected values are given). ${ }^{1} \mathrm{H}(300 \mathrm{MHz})$ and ${ }^{13} \mathrm{C}(75 \mathrm{MHz}) \mathrm{NMR}$ spectra were measured with a Bruker DPX 300 spectrometer and ${ }^{19} \mathrm{~F}$ NMR (235 MHz) with Brucker Avance 250 spectrometer. 13C NMR assignments were made using DEPT spectra. Microanalyses were performed on a EuroEA3000 (Eurovector). The mass spectra were run on MAT-731 and MAT CH-7 instruments. X-Ray crystallography data were collected with a STOE IPDS II instrument, using graphite monochromatized MoK $\alpha$ radiation $(\lambda=0.71073 \AA)$. Complete crystallographic data, as a CIF file, have been deposited with the Cambridge Crystallographic Data Centre (CCDC Nos 670514 \& 670515). Copies can be obtained free of charge from: CCDC, 12 Union Road, Cambridge CB2 1EZ, UK. (e-mail: deposit@,ccdc.cam.ac.uk, http://www.ccdc.cam.ac.uk/deposit).

The reaction mixtures were separated by column chromatography on Merck-60 silica gel. Methylene chloride and chloroform were dried by distillation over $\mathrm{P}_{2} \mathrm{O}_{5}$. Commercial 
tetrabutylammonium bromide was dried in a dessicator over $\mathrm{P}_{2} \mathrm{O}_{5}$. Compounds 1a-d were prepared by condensation of the corresponding aldehyde and amine. Active lead was prepared as described earlier. $^{7 \mathrm{a}}$

\section{Computational details}

All calculations were performed with the B3LYP density functional method ${ }^{14}$ by using the Gaussian suite of quantum chemical programs. ${ }^{11}$ Geometry optimizations of intermediates, transition states, reactants, and products in the gas phase were performed at the B3LYP/6-31G* level using Gaussian 03. Stationary points on the respective potential-energy surfaces were characterized at the same level of theory by evaluating the corresponding Hessian indices. Careful verification of the unique imaginary frequencies for transition states was carried out to check whether the frequency indeed pertains to the desired reaction coordinate. Intrinsic reaction coordinates (IRC) were calculated to authenticate all transition states. ${ }^{15}$

\section{A typical experimental procedure $(A)$ for the reaction of difluorocarbene with azadienes}

Azadiene 1a (1.00 g, $3.36 \mathrm{mmol}), \mathrm{Bu}_{4} \mathrm{NBr}$ (1.30 g, $\left.4.04 \mathrm{mmol}\right)$, and $\mathrm{CF}_{2} \mathrm{Br}_{2}$ (1.06 g, $\left.5.04 \mathrm{mmol}\right)$ were added to a flask charged with freshly prepared active lead $(0.836 \mathrm{~g}, 4.04 \mathrm{mmol})$ under a layer of $\mathrm{CH}_{2} \mathrm{Cl}_{2}(10 \mathrm{~mL})$. The flask was closed with a stopper which was fixed so as to keep a slight excess pressure, immersed in a sonic cleaner $(37 \mathrm{kHz}, 160 \mathrm{~W})$ and irradiated with ultrasound until the lead was consumed completely $(5 \mathrm{~h})$. The solvent was removed under reduced pressure and the residue was subjected to column chromatography on silica gel (eluent: hexane-ether) to afford after recrystallization $0.250 \mathrm{~g}$ (23\%) of 1-benzyl-2-fluoro-3,5-diphenyl$1 \mathrm{H}$-pyrrole 2 as a colorless solid: $\mathrm{mp} 74-75{ }^{\circ} \mathrm{C}$ (hexane-ether). ${ }^{1} \mathrm{H} \mathrm{NMR}\left(300 \mathrm{MHz}, \mathrm{CDCl}_{3}\right): \delta$ $5.14\left(2 \mathrm{H}, \mathrm{s}, \mathrm{CH}_{2}\right), 6.44\left(1 \mathrm{H}, \mathrm{d},{ }^{4} J_{\mathrm{HF}}=6.5 \mathrm{~Hz}, \mathrm{C}^{4}-\mathrm{H}\right), 7.04-7.62\left(15 \mathrm{H}, \mathrm{m}, \mathrm{CH}_{\text {arom }}\right) .{ }^{13} \mathrm{C} \mathrm{NMR}(75$ $\left.\mathrm{MHz}, \mathrm{CDCl}_{3}\right): \delta 46.5\left(\mathrm{~d},{ }^{3} \mathrm{~J}=1.8 \mathrm{~Hz}, \mathrm{CH}_{2}\right), 101.3\left(\mathrm{~d},{ }^{3} J_{\mathrm{CF}}=4 \mathrm{~Hz}, \mathrm{C}^{5}\right), 104.2\left(\mathrm{~d},{ }^{3} J_{\mathrm{CF}}=3 \mathrm{~Hz}, \mathrm{C}^{4}\right)$, $125.3,125.5,125.5,126.1,126.4,127.3,127.4,128.6,128.6,128.7,132.3,137.5\left(\mathrm{C}_{\text {arom }}\right), 133.0$ $\left(\mathrm{d},{ }^{2} J_{\mathrm{CF}}=5 \mathrm{~Hz}, \mathrm{C}^{3}\right), 145.1\left(\mathrm{~d},{ }^{1} J_{\mathrm{CF}}=267 \mathrm{~Hz}, \mathrm{C}^{2}\right) .{ }^{19} \mathrm{~F}$ NMR $\left(235 \mathrm{MHz}, \mathrm{CDCl}_{3}\right): \delta 24.2 . \mathrm{HRMS}$ : $\mathrm{m} / z$ calcd for $\mathrm{C}_{23} \mathrm{H}_{18} \mathrm{FN}$ : 327.1423; found 327.1428.

Pyrrole 2. $0.055 \mathrm{~g}$ (17\%) and 1-benzyl-2-(trifluoromethyl)-3,5-diphenyl-1H-pyrrole (3). $0.050 \mathrm{~g}(13 \%)$ were prepared by the typical procedure $(A)$ from azadiene 1a $(0.297 \mathrm{~g}, 1 \mathrm{mmol})$, $\mathrm{Bu}_{4} \mathrm{NBr}(0.645 \mathrm{~g}, 2 \mathrm{mmol})$, and $\mathrm{CF}_{2} \mathrm{Br}_{2}(0.525 \mathrm{~g}, 2.5 \mathrm{mmol})$ and active lead (0.414 g, $\left.2 \mathrm{mmol}\right)$ for $60 \mathrm{~h}$. A mixture of hexane and benzene was used for column chromatography. Pyrrole 3: colorless solid: $\mathrm{mp} 84-85{ }^{\circ} \mathrm{C}$ (ether). ${ }^{1} \mathrm{H}$ NMR $\left(300 \mathrm{MHz}, \mathrm{CDCl}_{3}\right): \delta 5.36\left(2 \mathrm{H}, \mathrm{s}, \mathrm{CH}_{2}\right), 6.36(1 \mathrm{H}$, $\left.\mathrm{s}, \mathrm{C}^{4}-\mathrm{H}\right), 6.93-7.51\left(15 \mathrm{H}, \mathrm{m}, \mathrm{CH}_{\text {arom }}\right) .{ }^{13} \mathrm{C} \mathrm{NMR}\left(75 \mathrm{MHz}, \mathrm{CDCl}_{3}\right): \delta 49.9\left(\mathrm{q},{ }^{4} J_{\mathrm{CF}}=2.7 \mathrm{~Hz}\right.$, $\left.\mathrm{CH}_{2}\right), 111.6\left(\mathrm{C}^{4}\right), 117.4\left(\mathrm{q},{ }^{2} J_{\mathrm{CF}}=36 \mathrm{~Hz}, \mathrm{C}^{2}\right), 122.4\left(\mathrm{q},{ }^{1} J_{\mathrm{CF}}=269 \mathrm{~Hz}, \mathrm{CF}_{3}\right), 125.5,127.0,127.1$, $127.9,128.3,128.4,128.5,129.4,129.5,131.7,135.1,138.4\left(\mathrm{C}_{\text {arom }}\right), 129.7$ (q, $\left.{ }^{3} J=2.9 \mathrm{~Hz}, \mathrm{C}^{3}\right)$, $139.2\left(\mathrm{q},{ }^{4} J_{\mathrm{CF}}=2 \mathrm{~Hz}, \mathrm{C}^{5}\right) .{ }^{19} \mathrm{~F}$ NMR $\left(235 \mathrm{MHz}, \mathrm{CDCl}_{3}\right)$ : 108.9. Anal. Calcd for $\mathrm{C}_{24} \mathrm{H}_{18} \mathrm{~F}_{3} \mathrm{~N}$ : C 76.4, H 4.8, N 3.7. Found: C 75.6, H 5.2, N 3.5. Crystal data for 3. $\mathrm{C}_{24} \mathrm{H}_{18} \mathrm{~F}_{3} \mathrm{~N}$, MW 377.39, orthorhombic, P2(1)2(1)2(1) (N 19), $a=6.0064(4), b=12.7219(9), c=24.3210(17) \AA, V=$ 
1858.4(2) $\AA^{3}, Z=4, T=133(2) \mathrm{K}, \mathrm{F}(000)=784, \mathrm{D}_{\text {calcd }}=1.349 \mathrm{~g} \cdot \mathrm{cm}^{-3}, R_{\text {all }}=0.0591, w R_{2}=$ $0.0995,31813$ reflections (3274 independent reflections with $R_{\text {int }}=0.0908$ ).

Pyrrole 3. $0.253 \mathrm{~g}$ (34\%) was prepared by the typical procedure $(A)$ from azadiene $1 \mathrm{a}(0.595 \mathrm{~g}$, $2 \mathrm{mmol}), \mathrm{Bu} 4 \mathrm{NBr}(1.934 \mathrm{~g}, 6 \mathrm{mmol})$, and $\mathrm{CF}_{2} \mathrm{Br}_{2}(1.574 \mathrm{~g}, 7.5 \mathrm{mmol})$ and active lead (1.243 g, 6 $\mathrm{mmol}$ ) for $10 \mathrm{~h}$. A mixture of hexane and ether was used for column chromatography.

\section{A typical experimental procedure $(B)$ for the reaction of difluorocarbene with azadienes}

A solution of azadiene 1a $(0.446 \mathrm{~g}, 1.5 \mathrm{mmol})$, and benzyltriethylammonium chloride $(0.102 \mathrm{~g}$, $0.45 \mathrm{mmol}$ ) in $20 \mathrm{ml}$ of chloroform was heated to the boiling point, and sodium trichloroacetate ( $3.5 \mathrm{~g}, 18.9 \mathrm{mmol}$ ) was added in small portions over a period of $1 \mathrm{~h}$ under vigorous stirring, maintaining the mixture slightly boiling. The solvent was removed under reduced pressure on a rotary evaporator, $50 \mathrm{ml}$ of dichloromethane was added to the residue, the mixture was filtered through a $1-\mathrm{cm}$ layer of celite, the filtrate was evaporated, and the residue the residue was subjected to column chromatography on silica gel (eluent: hexane-ether) to afford after recrystallization $0.230 \mathrm{~g}$ (35\%) of 1-benzyl-3,3-dichloro-4-phenyl-4-(E)-styryl-pyrrolidine2,5-dione (7) as a colorless solid: mp 122-123 ${ }^{\circ} \mathrm{C}$ (hexane-ether). $\left.{ }^{1} \mathrm{H} \mathrm{NMR} \mathrm{(300} \mathrm{MHz,} \mathrm{CDCl}_{3}\right): \delta$ $4.90\left(2 \mathrm{H}, \mathrm{s}, \mathrm{CH}_{2}\right), 6.37\left(1 \mathrm{H}, \mathrm{d},{ }^{3} J=16.0 \mathrm{~Hz}, \mathrm{CH}\right), 6.49\left(1 \mathrm{H}, \mathrm{d},{ }^{3} \mathrm{~J}=16.0 \mathrm{~Hz}, \mathrm{CH}\right), 7.20-7.66$ $\left(15 \mathrm{H}, \mathrm{m}, \mathrm{CH}_{\text {arom }}\right) .{ }^{13} \mathrm{C} \mathrm{NMR}\left(75 \mathrm{MHz}, \mathrm{CDCl}_{3}\right): \delta 43.7\left(\mathrm{CH}_{2}\right), 66.1\left(\mathrm{C}^{4}\right), 86.1\left(\mathrm{C}^{3}\right), 126.4,126.8$, 128.3, 128.4, 128.6, 128.7, 128.8, 128.9, 128.9 134.2, 134.6, $135.2\left(\mathrm{C}_{\text {arom }}\right), 128.8(\mathrm{CH} / \mathrm{C}=\mathrm{C})$, $136.1(\mathrm{CH} / \mathrm{C}=\mathrm{C}), 167.7(\mathrm{C}=\mathrm{O}), 171.4(\mathrm{C}=\mathrm{O})$. Anal. Calcd for $\mathrm{C}_{25} \mathrm{H}_{19} \mathrm{Cl}_{2} \mathrm{NO}_{2}: \mathrm{C} 68.8, \mathrm{H} 4.4, \mathrm{~N}$ 3.2. Found: C 68.9, $\mathrm{H} 4.5, \mathrm{~N} 3.1$.

1-Benzyl-2-chloro-3-methyl-1H-pyrrole (14a) 0.173 g (28\%), 1-benzyl-5-chloro-3-methyl1H-pyridin-2-one (15a) $0.027 \mathrm{~g}$ (4\%), and 1-benzyl-3,6-dichloro-5-methyl-2-trichloromethyl1,2-dihydropyridine (16a) $0.025 \mathrm{~g}(2 \%)$ were prepared by the typical procedure $(B)$ from azadiene $1 \mathbf{b}(0.477 \mathrm{~g}, 3 \mathrm{mmol})$ for $0.5 \mathrm{~h}$.

Pyrrole 14a. Colorless oil: ${ }^{1} \mathrm{H}$ NMR $\left(300 \mathrm{MHz}, \mathrm{CDCl}_{3}\right): \delta 2.13\left(3 \mathrm{H}, \mathrm{s}, \mathrm{CH}_{3}\right), 5.10\left(2 \mathrm{H}, \mathrm{s}, \mathrm{CH}_{2}\right)$, 6.10 д $\left(1 \mathrm{H}, \mathrm{d},{ }^{3} J=2.9 \mathrm{~Hz}, \mathrm{C}^{4}-\mathrm{H}\right), 6.63\left(1 \mathrm{H}, \mathrm{d},{ }^{3} J=2.9 \mathrm{~Hz}, \mathrm{C}^{5}-\mathrm{H}\right), 7.14-7.40\left(5 \mathrm{H}, \mathrm{m}, \mathrm{CH}_{\text {arom }}\right)$. ${ }^{13} \mathrm{C}$ NMR $\left(75 \mathrm{MHz}, \mathrm{CDCl}_{3}\right): \delta 11.1\left(\mathrm{CH}_{3}\right), 50.4\left(\mathrm{CH}_{2}\right), 109.3\left(\mathrm{C}^{4}\right), 113.7\left(\mathrm{C}^{3}\right), 115.1\left(\mathrm{C}^{2}\right), 119.5$ $\left(\mathrm{C}^{5}\right), 126.8,127.5,128.6,137.6\left(\mathrm{C}_{\text {arom }}\right)$. MS $(70 \mathrm{eV}) \mathrm{m} / \mathrm{z}(\%): 207\left([M+2]^{+}, 7\right), 205\left([M]^{+}, 22\right)$, 92 (10), 91 (100), 89 (4), 65 (17), 51 (7). Anal. Calcd for $\mathrm{C}_{12} \mathrm{H}_{12} \mathrm{ClN}$ : C 70.1, H 5.9, N 6.8. Found: C 70.4, H 5.5, N 6.7.

Pyridone 15a. Colorless solid, mp 158-158.5 ${ }^{\circ} \mathrm{C}$ (hexane-ether). ${ }^{1} \mathrm{H}$ NMR $\left(300 \mathrm{MHz}, \mathrm{CDCl}_{3}\right): \delta$ $2.41\left(3 \mathrm{H}, \mathrm{s}, \mathrm{CH}_{3}\right), 5.54\left(2 \mathrm{H}, \mathrm{s}, \mathrm{CH}_{2}\right), 6.08\left(1 \mathrm{H}, \mathrm{s}, \mathrm{C}^{4}-\mathrm{H}\right), 6.82\left(1 \mathrm{H}, \mathrm{s}, \mathrm{C}^{6}-\mathrm{H}\right), 7.10-7.32(5 \mathrm{H}$, $\left.\mathrm{CH}_{\text {arom }}\right) .{ }^{13} \mathrm{C}$ NMR $\left(75 \mathrm{MHz}, \mathrm{CDCl}_{3}\right): \delta 14.6\left(\mathrm{CH}_{3}\right), 52.7\left(\mathrm{CH}_{2}\right), 111.4\left(\mathrm{C}^{6}\right), 118.5\left(\mathrm{C}^{5}\right), 126.9$, 127.3, 128.5, $138.4\left(\mathrm{C}_{\text {arom }}\right), 129.1\left(\mathrm{C}^{4}\right), 133.3\left(\mathrm{C}^{3}\right), 166.8(\mathrm{C}=\mathrm{O})$. Anal. Calcd for $\mathrm{C}_{13} \mathrm{H}_{12} \mathrm{ClNO}: \mathrm{C}$ 66.8, H 5.2, N 6.0. Found: 66.8, H 5.2, N 5.9.

Pyridine 16a. Colorless solid, mp 70.5-71 ${ }^{\circ} \mathrm{C}(\mathrm{MeOH}) .{ }^{1} \mathrm{H}$ NMR $\left(300 \mathrm{MHz}, \mathrm{CDCl}_{3}\right): \delta 1.84$ $\left(3 \mathrm{H}, \mathrm{s}, \mathrm{CH}_{3}\right), 4.26\left(1 \mathrm{H}, \mathrm{d},{ }^{2} J=16.0 \mathrm{~Hz}, \mathrm{CH}_{2}\right), 5.20\left(1 \mathrm{H}, \mathrm{d},{ }^{2} J=16.0 \mathrm{~Hz}, \mathrm{CH}_{2}\right), 4.69\left(1 \mathrm{H}, \mathrm{s}, \mathrm{C}^{2}-\right.$ $\mathrm{H}), 6.34\left(1 \mathrm{H}, \mathrm{s}, \mathrm{C}^{4}-\mathrm{H}\right), 7.17-7.39\left(5 \mathrm{H}, \mathrm{m}, \mathrm{CH}_{\text {arom }}\right) .{ }^{13} \mathrm{C} \mathrm{NMR}\left(75 \mathrm{MHz}, \mathrm{CDCl}_{3}\right): \delta 16.5\left(\mathrm{CH}_{3}\right)$, $58.7\left(\mathrm{CH}_{2}\right), 78.2\left(\mathrm{C}^{2}\right), 101.5\left(\mathrm{CCl}_{3}\right), 111.3\left(\mathrm{C}^{5}\right), 112.1\left(\mathrm{C}^{3}\right), 127.3,127.9,128.7,132.2\left(\mathrm{C}_{\text {arom }}\right)$, 
130.8 $\left(\mathrm{C}^{4}\right)$, $136.9\left(\mathrm{C}^{6}\right)$. Anal. Calcd for $\mathrm{C}_{14} \mathrm{H}_{12} \mathrm{Cl}_{5} \mathrm{~N}$ : C 45.3, H 3.3, N 3.8. Found: C 45.3, H 3.6, $\mathrm{N}$ 3.7. Crystal data for 16a. $\mathrm{C}_{14} \mathrm{H}_{12} \mathrm{Cl}_{5} \mathrm{~N}$, MW 371.50, monoclinic, $P$ 2(1)/n (no. 14), $a=$ 9.7510(7), $b=13.9648(9), c=11.9486(8), \beta=104.99(0){ }^{\circ}, \AA, V=1571.68(18) \AA^{3}, Z=4, T=$ $293(2) \mathrm{K}, \mathrm{F}(000)=752, \mathrm{D}_{\text {calcd }}=1.570 \mathrm{~g} \cdot \mathrm{cm}^{-3}, R_{\text {all }}=0.0435, w R_{2}=0.1030,15638$ reflections (2644 independent reflections with $R_{\text {int }}=0.0753$ ).

Pyridine 16a. $0.025 \mathrm{~g}(3 \%)$ were obtained also from pyrrole 14a $(0.500 \mathrm{~g}, 2.44 \mathrm{mmol})$ by the typical procedure $(B)$ for $0.8 \mathrm{~h}$.

1-Benzyl-2-chloro-3-phenyl-1H-pyrrole (14b) 0.153 g (25\%), and 1-benzyl-3,6-dichloro-5phenyl-2-trichloromethyl-1,2-dihydropyridine (16b) $0.050 \mathrm{~g}(5 \%)$ were prepared by the typical procedure $(B)$ from azadiene $1 \mathbf{b}(0.509 \mathrm{~g}, 2.3 \mathrm{mmol})$ for $0.5 \mathrm{~h}$.

Pyrrole 14b. Colorless oil. ${ }^{1} \mathrm{H}$ NMR $\left(300 \mathrm{MHz}, \mathrm{CDCl}_{3}\right): \delta 5.20\left(2 \mathrm{H}, \mathrm{s}, \mathrm{CH}_{2}\right), 6.50\left(1 \mathrm{H}, \mathrm{d},{ }^{3} J=\right.$ $\left.3.1 \mathrm{~Hz}, \mathrm{C}^{4}-\mathrm{H}\right), 6.77\left(1 \mathrm{H}, \mathrm{d},{ }^{3} \mathrm{~J}=3.1 \mathrm{~Hz}, \mathrm{C}^{5}-\mathrm{H}\right), 7.20-7.77\left(10 \mathrm{H}, \mathrm{CH}_{\text {arom }}\right) .{ }^{13} \mathrm{C} \mathrm{NMR}(75 \mathrm{MHz}$, $\left.\mathrm{CDCl}_{3}\right): \delta 50.5\left(\mathrm{CH}_{2}\right), 108.2\left(\mathrm{C}^{4}\right), 113.1\left(\mathrm{C}^{3}\right), 120.5\left(\mathrm{C}^{2}\right), 120.7\left(\mathrm{C}^{5}\right), 126.0,126.9,127.1,127.7$, 128.3, 128.7, 134.6, $137.1\left(\mathrm{C}_{\text {arom }}\right)$. Anal. Calcd for $\mathrm{C}_{17} \mathrm{H}_{14} \mathrm{ClN}$ : C 76.3, H 5.3, N 5.2. Found: $\mathrm{C}$ 76.4, H 5.6, N 5.5.

Pyridine 16b. Colorless solid, mp 77-78 ${ }^{\circ} \mathrm{C}(\mathrm{MeOH}) .{ }^{1} \mathrm{H} \mathrm{NMR}\left(300 \mathrm{MHz}, \mathrm{CDCl}_{3}\right): \delta 4.41(1 \mathrm{H}$, $\left.\mathrm{d},{ }^{2} J=16.0 \mathrm{~Hz}, \mathrm{CH}_{2}\right), 4.82\left(1 \mathrm{H}, \mathrm{s}, \mathrm{C}^{2}-\mathrm{H}\right), 5.39\left(1 \mathrm{H}, \mathrm{d},{ }^{2} J=16.0 \mathrm{~Hz}, \mathrm{CH}_{2}\right), 6.62\left(1 \mathrm{H}, \mathrm{s}, \mathrm{C}^{4}-\mathrm{H}\right)$, 7.24-7.41 (10H, $\left.\mathrm{CH}_{\text {arom }}\right) .{ }^{13} \mathrm{C}$ NMR $\left(75 \mathrm{MHz}, \mathrm{CDCl}_{3}\right): \delta 59.1\left(\mathrm{CH}_{2}\right), 78.0\left(\mathrm{C}^{2}\right), 101.4\left(\mathrm{CCl}_{3}\right)$, $112.4\left(\mathrm{C}^{5}\right), 116.8\left(\mathrm{C}^{3}\right), 127.2,127.2,128.1,128.2,128.8,128.9,132.7,136.7\left(\mathrm{C}_{\text {arom }}\right), 130.4\left(\mathrm{C}^{4}\right)$, $136.7\left(\mathrm{C}^{6}\right)$. Anal. Calcd for $\mathrm{C}_{19} \mathrm{H}_{14} \mathrm{Cl}_{5} \mathrm{~N}$ : C 52.6, H 3.3, N 3.2. Found: 52.8, H 3.4, N 3.2.

\section{Acknowledgements}

We gratefully acknowledge the Russian Foundation for Basic Research (project no. 08-0300112) for support of this research.

\section{References and Notes}

1. Khlebnikov, A. F.; Novikov, M. S.; Kostikov, R. R. Adv. Heterocycl. Chem. 1996, 65, 93.

2. Khlebnikov, A. F.; Novikov, M. S.; Kostikov, R. R. Russ. Chem. Rev. 2005, 74, 171.

3. Kostikov, R. R.; Khlebnikov, A. F.; Ogloblin, K. A. J. Org. Chem. USSR (Engl. Transl.) 1977, 13, 1721.

4. (a) Romashin, Y. N.; Liu, M. T. H.; Bonneau, R. A J. Chem. Soc. Chem. Commun. 1999, 447. (b) Bonneau, R.; Romashin, Y. N.; Liu, M. T. H. J. Photochem. Photobiol. A: Chemistry 1999, 126, 31. (c) Romashin, Y. N.; Liu, M. T. H.; Ma, W.; Moss, R. A. Tetrahedron Lett. 1999, 40, 7163.

5. (a) Novikov, M. S.; Khlebnikov, A. F.; Egarmin, M. A.; Kopf, J.; Kostikov R. R. Russ. J. Org. Chem. 2004, 40, 1493. (b) Novikov, M. S.; Khlebnikov, A. F.; Voznyi, I. V.; Besedina, 
O. V.; Kostikov, R. R. Russ. J. Org. Chem. 2005, 41, 361. (c) Novikov, M. S.; Khlebnikov, A. F.; Shevchenko, M. V.; Kostikov, R. R., Vidovic, D. Russ. J. Org. Chem. 2005, 41, 1496. (d) Novikov, M. S.; Khlebnikov, A. F.; Egarmin, M. A.; Shevchenko, M. V.; Khlebnikov, V. A.; Kostikov, R. R., Vidovic, D. Russ. J. Org. Chem. 2006, 42, 1800.

6. (a) Voznyi, I. V.; Novikov, M. S.; Khlebnikov, A. F. Synlett 2005, 1006. (b) Voznyi, I. V.; Novikov, M. S.; Khlebnikov, A. F.; Kostikov, R. R. Russ. J. Org. Chem. 2006, 42, 689.

7. (a) Novikov, M. S.; Khlebnikov, A. F.; Sidorina, E. S.; Kostikov, R. R. J. Chem. Soc., Perkin Trans. 1 2000, 231. (b) Novikov, M. S.; Khlebnikov, A. F.; Besedina, O. V.; Kostikov, R. R. Tetrahedron Lett. 2001, 42, 533. (c) Novikov, M. S.; Khlebnikov, A. F.; Sidorina, E. S.; Masalev, A. E.; Kopf, J.; Kostikov, R. R. Russ. J. Org. Chem. 2002, 38, 672. (d) Novikov, M. S.; Khlebnikov, A. F.; Kostikov, R. R. Russ. J. Org. Chem. 2002, 38, 1647. (e) Novikov, M. S.; Khlebnikov, A. F.; Shevchenko, M. V. J. Fluor. Chem. 2003, 123, 177.

8. (a) Van Hende, E.; Verniest, G.; Surmont, R.; De Kimpe, N. Org. Lett. 2007, 9, 2935. (b) Verniest, G.; Colpaert, F. Van Hende, E.; De Kimpe, N. J. Org. Chem. 2007, 72, 8569.

9. Kostikov, R. R.; Khlebnikov, A. F.; Ogloblin, K. A. Chem. Heterocycl. Comp. $1978,37$.

10. (a) Khlebnikov, A. F.; Kostik, E. I.; Novikov, M. S.; Kostikov, R. R. J. Org. Chem. USSR (Engl. Transl.) 1989, 25, 1468. (b) Khlebnikov, A. F.; Nikiforova, T. Yu.; Kostikov, R. R. Russ. J. Org. Chem. 1999, 35, 707.

11. Frisch, M. J.; Trucks, G. W. Schlegel, H. B.; Scuseria, G.E.; Robb, M.A.; Cheeseman, J.R.; Montgomery, J. A. Jr.; Vreven, T.; Kudin, K. N.; Burant, J. C.; Millam, J. M.; Iyengar, S. S.; Tomasi, J.; Barone, V.; Mennucci, B.; Cossi, M.; Scalmani, G.; Rega, N.; Petersson, G. A.; Nakatsuji, H.; Hada, M.; Ehara, M.; Toyota, K.; Fukuda, R.; Hasegawa, J.; Ishida, M.; Nakajima, T.; Honda, Y.; Kitao, O.; Nakai, H.; Klene, M.; Li, X.; Knox, J.E.; Hratchian, H.P.; Cross, J. B.; Adamo, C.; Jaramillo, J.; Gomperts, R.; Stratmann, R.E.; Yazyev, O.; Austin ,A.J.; Cammi, R.; Pomelli, C.; Ochterski, J. W.; Ayala, P.Y.; Morokuma, K.; Voth, G. A.; Salvador, P.; Dannenberg, J.J.; Zakrzewski, V.G.; Dapprich, S.; Daniels,A.D.; Strain, M. C.; Farkas, O.; Malick, D. K.; Rabuck, A. D.; Raghavachari, K.; Foresman, J. B.; Ortiz, J. V.; Cui, Q.; Baboul, A. G.; Clifford, S.; Cioslowski, J.; Stefanov, B. B.; Liu, G.; Liashenko, A.; Piskorz, P.; Komaromi, I.; Martin, R. L.; Fox, D. J.; Keith, T.; Al-Laham, M. A.; Peng, C. Y.; Nanayakkara, A.; Challacombe, M.; Gill, P. M. W.; Johnson, B.; Chen, W.; Wong, M. W.; Gonzalez, C.; Pople, J. A. Gaussian 03, Revision B.05, Gaussian, Inc.: Pittsburgh PA, 2003.

12. Hunter, D. H.; Steiner, R. P. Can. J. Chem. 1975, 53, 355.

13. (a) Fritz, H. P.; Kornrumpf, W. Z. Naturfosch 1981, 36b, 1375. (b) Tyerman, W. J. R. Trans. Faraday Soc. 1969, 65, 1188.

14. (a) Becke, A. D. J. Chem. Phys. 1993, 98, 5648. (b) Becke, A. D. Phys. Rev. A 1998, 38, 3098. (c) Lee, C.; Yang, W.; Parr, R. G. Phys. Rev. B 1998, 37, 785.

15. (a) Gonzalez, C.; Schlegel, H. B. J. Chem. Phys. 1989, 90, 2154. (b) Gonzalez, C.; Schlegel, H. B. J. Phys. Chem. 1990, 94, 5523. 